REVIEW ARTICLE OPEN

\title{
Biological functions and clinical significance of long noncoding RNAs in bladder cancer
}

\author{
Yan Zhang ${ }^{1,2}$, Xianwu Chen ${ }^{1,2}$, Juntao $\operatorname{Lin}^{1}$ and Xiaodong Jin $\mathbb{D}^{1 凶}$
}

(c) The Author(s) 2021

Bladder cancer $(\mathrm{BCa})$ is one of the 10 most common cancers with high morbidity and mortality worldwide. Long noncoding RNAs (IncRNAs), a large class of noncoding RNA transcripts, consist of more than 200 nucleotides and play a significant role in the regulation of molecular interactions and cellular pathways during the occurrence and development of various cancers. In recent years, with the rapid advancement of high-throughput gene sequencing technology, several differentially expressed IncRNAs have been discovered in $\mathrm{BCa}$, and their functions have been proven to have an impact on BCa development, such as cell growth and proliferation, metastasis, epithelial-mesenchymal transition (EMT), angiogenesis, and drug-resistance. Furthermore, evidence suggests that IncRNAs are significantly associated with BCa patients' clinicopathological characteristics, especially tumor grade, TNM stage, and clinical progression stage. In addition, IncRNAs have the potential to more accurately predict BCa patient prognosis, suggesting their potential as diagnostic and prognostic biomarkers for BCa patients in the future. In this review, we briefly summarize and discuss recent research progress on BCa-associated IncRNAs, while focusing on their biological functions and mechanisms, clinical significance, and targeted therapy in $\mathrm{BCa}$ oncogenesis and malignant progression.

Cell Death Discovery (2021)7:278; https://doi.org/10.1038/s41420-021-00665-z

\section{FACTS}

- Bladder cancer is one of the top 10 cancers with high morbidity and mortality worldwide.

- LncRNAs are a large class of noncoding RNA transcripts longer than 200 nucleotides that play important roles in biological processes, especially in cancer progression.

- LncRNAs can regulate the progression of bladder cancer.

- LncRNAs have the potential to accurately predict BCa patient prognosis and associated with clinicopathologic characteristics.

\section{OPEN QUESTIONS}

- Are IncRNAs involved in the posttranscriptional regulation of bladder cancer genes?

- How can we target IncRNAs to modulate the mechanism of bladder cancer progression?

- Are more multicenter cohort studies needed to verify the clinical value of IncRNAs in bladder cancer?

\section{BACKGROUND}

As one of the most common urinary malignancies, bladder cancer (BCa) ranks within the top 10 cancers associated with high morbidity and mortality globally [1]. As a highly heterogeneous cancer, non-muscle-invasive BCa accounts for more than $75 \%$ of all $\mathrm{BCa}$ cases, while muscle-invasive $\mathrm{BCa}$ accounts for the remainders [2]. In current clinical practice, pathological biopsy with cystoscopy is considered to be the most reliable method for detecting $\mathrm{BCa}$ [3]. A major achievement in $\mathrm{BCa}$ therapies has been obtained. There is a wide range of $\mathrm{BCa}$ treatment plans, including surgical resection, chemotherapy, radiotherapy, and immunotherapy [4]. Despite recent progress in various cystoscopy and treatment options, the outcome of $\mathrm{BCa}$ patients is still not optimistic. The main reason for the low 5-year survival rate of advanced $\mathrm{BCa}$ patients is postoperative recurrence and uncontrollable distant metastasis [5]. Therefore, elucidating the molecular mechanisms and identifying potential therapeutic targets in $\mathrm{BCa}$ patients are of great significance.

The Cancer Genome Atlas (TCGA) has identified molecular aberrations at the DNA, RNA, protein, and epigenetic levels via massive numbers of human tumors analyzed. These sequencing results have confirmed that only $1-2 \%$ of human DNA is proteincoding genes, while more than $90 \%$ of the human gene (called noncoding RNAs) is transcribed to a universal team of RNA transcripts except protein-coding functions [6-8]. Long noncoding RNAs (IncRNAs), a large class of noncoding RNA transcripts, consist of more than 200 nucleotides [9]. With the rapid development of high-throughput genome sequencing technologies, IncRNAs are reported to play important roles in biological processes, especially in cancer progression, cell proliferation, differentiation, and metastasis. Several IncRNAs such as HOTAIR, PVT1, and H19, have

\footnotetext{
${ }^{1}$ Department of Urology, The First Affiliated Hospital, Zhejiang University School of Medicine, Hangzhou, Zhejiang, China. ${ }^{2}$ These authors contributed equally: Yan Zhang, Xianwu Chen. ${ }^{凶}$ email: xiaodong-jin@zju.edu.cn
} 
been found to influence carcinogenesis and progression in colon cancer [9]. Recent studies have demonstrated that IncRNAs play important roles in tumor development and progression and aberrant expression of IncRNAs has been reported in BCa [10]. However, there are no studies that have systematically analyzed the role and mechanism played by IncRNAs in BCa. This review summarizes the functions and mechanisms, and clinical significance of IncRNAs in the oncogenesis and malignancy of human $\mathrm{BCa}$ within the last 10 years.

\section{OVERVIEW OF LNCRNAS FUNCTIONS IN BCA}

Gibb et al. suggested that the importance of IncRNAs is rising, as they play roles in the cancer paradigm demonstrating potential functions in both oncogenic and tumor-suppressive pathways [11]. The study of IncRNAs in cancer progression has gradually developed. Studies have demonstrated that the expression of IncRNAs is related to the development and progression of BCa. It has been reported that IncRNAs are engaged in the regulation of cell growth and proliferation, tumor progression, and drug chemoresistance in BCa cells (Table 1).

\section{CELL PROLIFERATION}

Aberrant tumor cell proliferation can sustain active proliferative states, playing an important role in tumor growth [12]. UCA1 was the first reported oncogenic IncRNA and is overexpressed enormously in $\mathrm{BCa}$ and promotes $\mathrm{BCa}$ progression by regulating several targets and pathways [13]. First, UCA1 interferes with the chromatin redesigning activity of BRG1 and binds to the P21 promoter, thereby proliferating tumor cells [14]. The transcriptional activation of UCA1 through C/EBPa additionally contributes to elevated viability and reduced apoptosis of $\mathrm{BCa}$ cells [15]. Second, UCA1 regulates miR-16/GLS2 expression and suppresses ROS formation [16]. Via the mTOR/STAT3cascade and the miR143/ HK2 axis, UCA1 also enhances cancer cell glucose metabolism [17]. Third, UCA1 was also reported to influence AKT expression and activity, and its alteration parallels the expression and phosphorylation of CREB to promote the proliferation and regulation of the cell cycle [18]. BMP9 upregulates AKT phosphorylation levels and increases UCA1 expression to promote the proliferation and metastasis of BCa cells [19].

The PI3K/AKT signaling pathway is the most generally activated pathway in human malignant tumors, and its activation increases the activity of nutrient transporters and metabolic enzymes to reprogram cellular metabolism inflicting tumor cell proliferation [20]. HULC promotes BCa cell proliferation via regulation of the $\mathrm{PI} 3 \mathrm{~K} / \mathrm{AKT}$ signaling pathway and ZIC2 [21]. ATB, an oncogene, is overexpressed to promote cell proliferation and migration by regulating miR-126/KRAS via the PI3K/AKT signaling pathway [22]. FOXD2-AS1 negatively regulates the expression of TRIB3 (a negative regulator of AKT) and promotes cell proliferation, and migration [23]. However, the expression of LINC00641 is significantly decreased in $\mathrm{BCa}$, and its upregulation markedly inhibits the proliferation, and metastasis of BCa cells via the PTEN/ PI3K/AKT axis [24]. LOC572558 inhibits BCa cell proliferation by regulating the AKT/MDM2/P53 axis [25]. For other pathways, HCG22 negatively regulates the PTBP1-mediated Warburg effect by destabilizing human antigen $R$ (HuR) to suppress cell proliferation, and progression [26]. IGFBP4-1 promotes cell proliferation and cell cycle progression and inhibits cell apoptosis by activating the JAK/STAT signaling pathway [27]. E2F4 is reported to be critical for MIR497HG silencing. MIR497HG suppresses cell proliferation, and metastasis by inhibiting YAP, SMAD3, BIRC5, and CCND1 expression (key genes of Hippo/Yap and TGF-b/Smad signaling) [28].

According to various experimental studies, IncRNA functions as a competitive endogenous RNAs (ceRNAs) and competes for
microRNAs (miRNAs) to regulate the expression of certain target genes (Fig. 1) [29]. The ceRNA hypothesis has become a popular method for determining the function of a large number of uncharacterized IncRNAs [30]. The ceRNA hypothesis suggests that several IncRNAs are upregulated and promote BCa progression. BCAR4 promotes the proliferation, and tumor progression of $B C a$ cells by decreasing miR-370-3p level, and sponging miR-644a to modulate the expression of TLX1 [31, 32]. TMPO-AS1 contributes to proliferation by interacting with its sense mRNA TMPO or sponging miR-98-5p and upregulating EBF1 [33, 34]. KCNQ1OT1 has been found to regulate the miR-145-5p/PCBP2 and miR-218-5p/HS3ST3B1 axes, promote cell proliferation, and inhibit cell apoptosis [35, 36]. LINC00319 plays an oncogenic role in the regulation of proliferation and invasion by modulating the miR-3127/RAP2A and miR-4492/ROMO1 axes to regulate proliferation, migration, and invasion [37, 38]. ARAP1-AS1 promotes the proliferation and migration of $\mathrm{BCa}$ by regulating the miR4735-3p/NOTCH2 axis [39]. CALML3-AS1 promotes BCa cell proliferation, and metastasis, and inhibits apoptosis by regulating the ZBTB2-mediated suppression of miR-4316 [40]. CASC11 promotes the proliferation of $\mathrm{BCa}$ cells by regulating miR-150 expression [41]. DANCR promotes the proliferative, migrative, and invasive ability of BCa cells by modulating the miR-149/MSI2 axis as a ceRNA [42]. GAS6-AS2 can function as a ceRNA by directly sponging miR-298 and further regulating the expression of CDK9 to promote cell proliferation and metastasis [43]. Overexpressed PVT1 downregulates miR-31 to enhance the expression of CDK1 and facilitate $\mathrm{BCa}$ cell proliferation, migration, and invasion [44]. SLCO4A1-AS1 promotes proliferation, migration, and invasion by sponging miR-335-5p to upregulate OCT4 expression [45]. DDX11-AS1 significantly promotes cell proliferation via the miR2355-5p/LAMB3 axis [46]. ZNFX1-AS1 targeting miR-193a-3p/ SDC1 regulates cell proliferation, migration, and invasion of $\mathrm{BCa}$ cells [47]. RNF144A-AS1 enhances the malignant behaviors of $\mathrm{BCa}$ cells via the miR-455-5p/SOX11 axis [48]. TUG1 inhibits miR-29c expression to promote cancer cell proliferation, metastasis [49]. ZFAS1 promotes cell proliferation, and metastasis by downregulating miR-329 [50]. XIST downregulates miR-133a, or P53/ TET1 to promote BCa progression [51, 52]. ITGB1 promotes cell proliferation by regulating miR-10a expression [53]. ROR1-AS1 is upregulated in $\mathrm{BCa}$ and promotes cell growth and migration by regulating miR-504 [54]. LncRNAs can also function as inhibitors and are downregulated in BCa. MBNL1-AS1 inhibits BCa cell proliferation and enhances cell apoptosis via targeting of the miR135a-5p/PHLPP2/FOXO1 and miR-362-5p/QKI axes [55, 56]. HCG18 suppresses cell proliferation and migration by directly sponging miR-34c-5p and regulating the expression of NOTCH1 [57]. YMT1JP suppresses cell proliferation, cell cycle progression, and invasion by regulating miR-214-3p [58].

In addition to their binding to miRNAs, some newly reported IncRNAs directly bind proteins and participate in proliferation processes. The knockdown of ZFAS1 represses BCa cell proliferation by upregulating KLF2 and NKD2 expression [59]. SNHG5 promotes BCa cell proliferation by targeting P27 [60]. GCInc1 has been shown to significantly promote cell proliferation, metastasis, and invasiveness in BCa via the LIN28B/let-7a/MYC axis [61]. Upregulation of CASC9 is induced by STAT3 to promote BCa cell proliferation, migration, and invasion by interacting with EZH2 and affecting the expression of PTEN [62]. As a tumor suppressor, GAS5 has been reported to inhibit BCa proliferation by regulating CDK6 and CCL1 expression $[63,64]$. BRE-AS1 inhibits cell proliferation and accelerates cell apoptosis by mediating STAT3 expression [65]. ZNF503-AS1 can recruit transcription factor GATA6 to upregulate SLC8A1 expression, thereby increasing the intracellular $\mathrm{Ca}^{2+}$ concentration, repressing proliferation, and enhancing the apoptosis of BCa cells [66].

In addition, downregulation of LINC00346 inhibits BCa cell proliferation and migration, and induces cell apoptosis [67]. 
Table 1. Overview of deregulated IncRNAs in BCa.

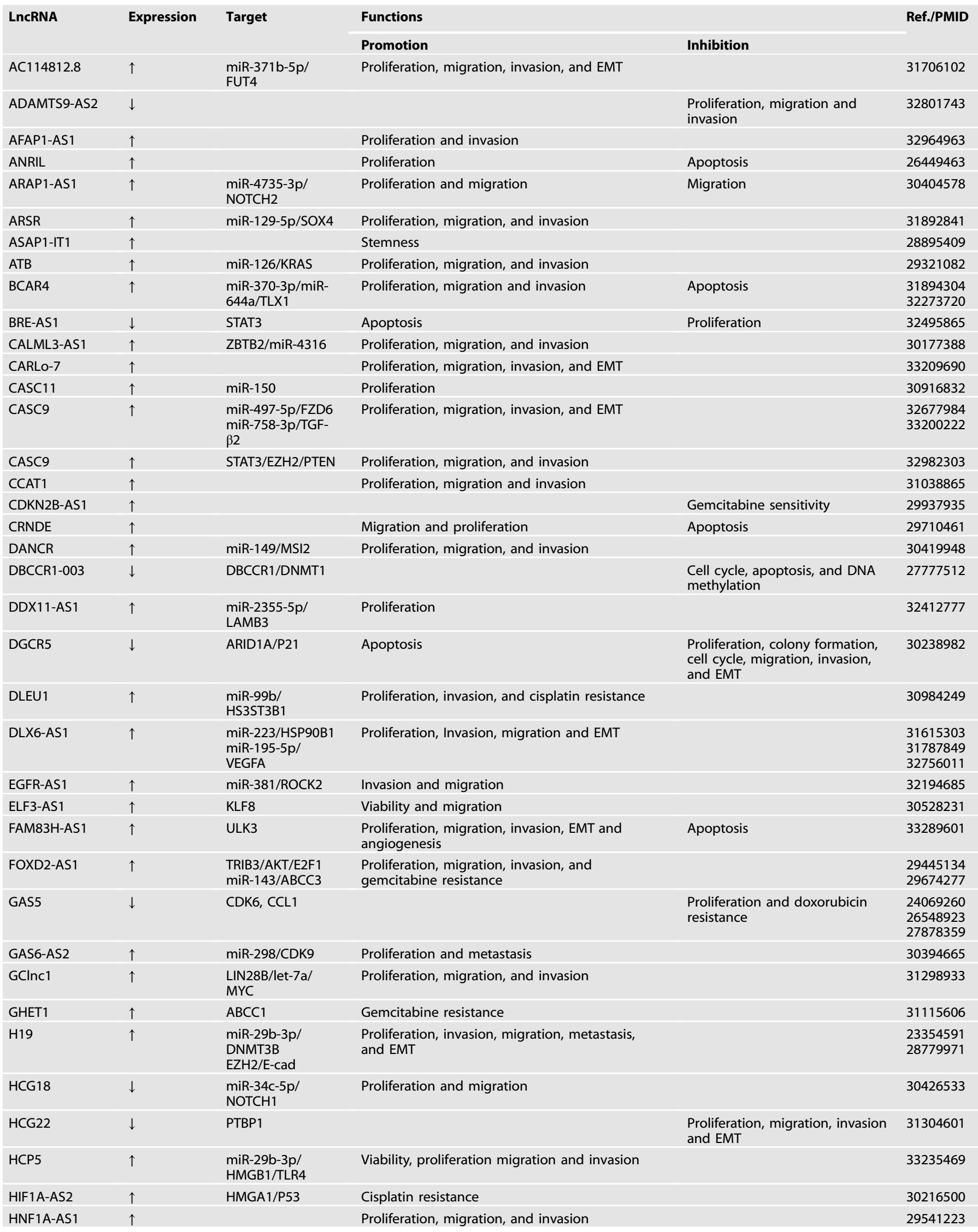


Table 1 continued

\begin{tabular}{|c|c|c|c|c|c|}
\hline \multirow[t]{2}{*}{ LncRNA } & \multirow[t]{2}{*}{ Expression } & \multirow[t]{2}{*}{ Target } & \multicolumn{2}{|l|}{ Functions } & \multirow[t]{2}{*}{ Ref./PMID } \\
\hline & & & Promotion & Inhibition & \\
\hline HOTAIR & $\uparrow$ & miR-205/CCNJ & Proliferation, migration and invasion & $\begin{array}{l}\text { Chemosensitivity to doxorubicin } \\
\text { and cell apoptosis }\end{array}$ & $\begin{array}{l}26469956 \\
26781446\end{array}$ \\
\hline HULC & $\uparrow$ & $\mathrm{ZIC2}$ & Proliferation & Apoptosis & 28946549 \\
\hline IGFBP4-1 & $\uparrow$ & & Proliferation and cell cycle & Apoptosis & 32760196 \\
\hline ITGB1 & $\uparrow$ & miR-10a & Proliferation & & 31486485 \\
\hline KTN1-AS1 & $\uparrow$ & KTN1 & Proliferation, invasion, and migration & & 33480975 \\
\hline LBCS & $\downarrow$ & Sox 2 & & $\begin{array}{l}\text { Self-renewal and } \\
\text { chemoresistance }\end{array}$ & 30397178 \\
\hline LET & $\downarrow$ & NF90/miR-145 & Gemcitabine chemoresistance and stemness & & 28839463 \\
\hline LINC00346 & $\uparrow$ & & Proliferation and migration & Cell cycle and apoptosis & 28705739 \\
\hline LINC00460 & $\uparrow$ & & Proliferation and migration & & 30881506 \\
\hline LINC00511 & $\uparrow$ & miR-15a-3p & Proliferation, migration, and invasion & Apoptosis & 30042171 \\
\hline LINC00612 & $\uparrow$ & miR-590/PHF14 & Proliferation, invasion, and EMT & & 30940184 \\
\hline LINC00641 & $\downarrow$ & $\begin{array}{l}\text { miR-197-3p/ } \\
\text { KLF10/PTEN }\end{array}$ & & $\begin{array}{l}\text { Proliferation migration, and } \\
\text { invasion }\end{array}$ & 30060954 \\
\hline LINC00675 & $\downarrow$ & & Migration, invasion, and proliferation & & 32367602 \\
\hline LINC00857 & $\uparrow$ & LMAN1 & Platinum-based chemotherapy resistance & & 29856124 \\
\hline LINC01106 & $\uparrow$ & $\begin{array}{l}\text { miR-3612/ELK3 } \\
\text { DKC1/HOXD8 }\end{array}$ & Proliferation, migration, invasion, and EMT & & 33311496 \\
\hline LINC01140 & $\uparrow$ & miR-140-5p/FGF9 & $\begin{array}{l}\text { Cell aggressiveness and macrophage M2 } \\
\text { olarization }\end{array}$ & & 33234721 \\
\hline MAGI2-AS3 & $\downarrow$ & $\begin{array}{l}\text { miR-15b-5p/ } \\
\text { CCDC19 } \\
\text { miR-31-5p/TNS1 } \\
\text { MAGI2/PTEN }\end{array}$ & & $\begin{array}{l}\text { Proliferation, migration, } \\
\text { invasion, and EMT }\end{array}$ & $\begin{array}{l}30442369 \\
33104021 \\
33231563\end{array}$ \\
\hline MALAT1 & $\uparrow$ & $\begin{array}{l}\text { miR-125b/SIRT7 } \\
\text { miR-125b/Bcl-2/ } \\
\text { MMP-13 } \\
\text { SUZ12 } \\
\text { miR-124/FOXQ1 } \\
\text { miR-101-3p/ } \\
\text { VEGF-C }\end{array}$ & $\begin{array}{l}\text { Proliferation, migration, invasion, EMT, and } \\
\text { cisplatin resistance }\end{array}$ & Apoptosis & $\begin{array}{l}24449823 \\
24512850 \\
29151968 \\
29736319 \\
31650173\end{array}$ \\
\hline MBNL1-AS1 & $\downarrow$ & $\begin{array}{l}\text { miR-135a-5p/ } \\
\text { PHLPP2/FOXO1 } \\
\text { MiR-362-5p/QKI }\end{array}$ & Apoptosis & Proliferation & $\begin{array}{l}31769229 \\
32194406\end{array}$ \\
\hline MEG3 & $\downarrow$ & $\begin{array}{l}\text { miR-96/TPM1 } \\
\text { P53 }\end{array}$ & Apoptosis and cisplatin chemosensitivity & $\begin{array}{l}\text { Proliferation, cell cycle, } \\
\text { migration, and invasion }\end{array}$ & $\begin{array}{l}23295831 \\
29940769 \\
30461333\end{array}$ \\
\hline MIR143HG & $\downarrow$ & miR-1275/AXIN2 & & $\begin{array}{l}\text { Proliferation, cell cycle, } \\
\text { migration, and invasion }\end{array}$ & 30471109 \\
\hline MIR497HG & $\downarrow$ & E2F4 & & $\begin{array}{l}\text { Cell growth, migration, and } \\
\text { invasion }\end{array}$ & 33363213 \\
\hline MIR503HG & $\downarrow$ & & Apoptosis and cell cycle & $\begin{array}{l}\text { Proliferation, cell growth, cell } \\
\text { invasion, migration, and EMT }\end{array}$ & 30672010 \\
\hline
\end{tabular}




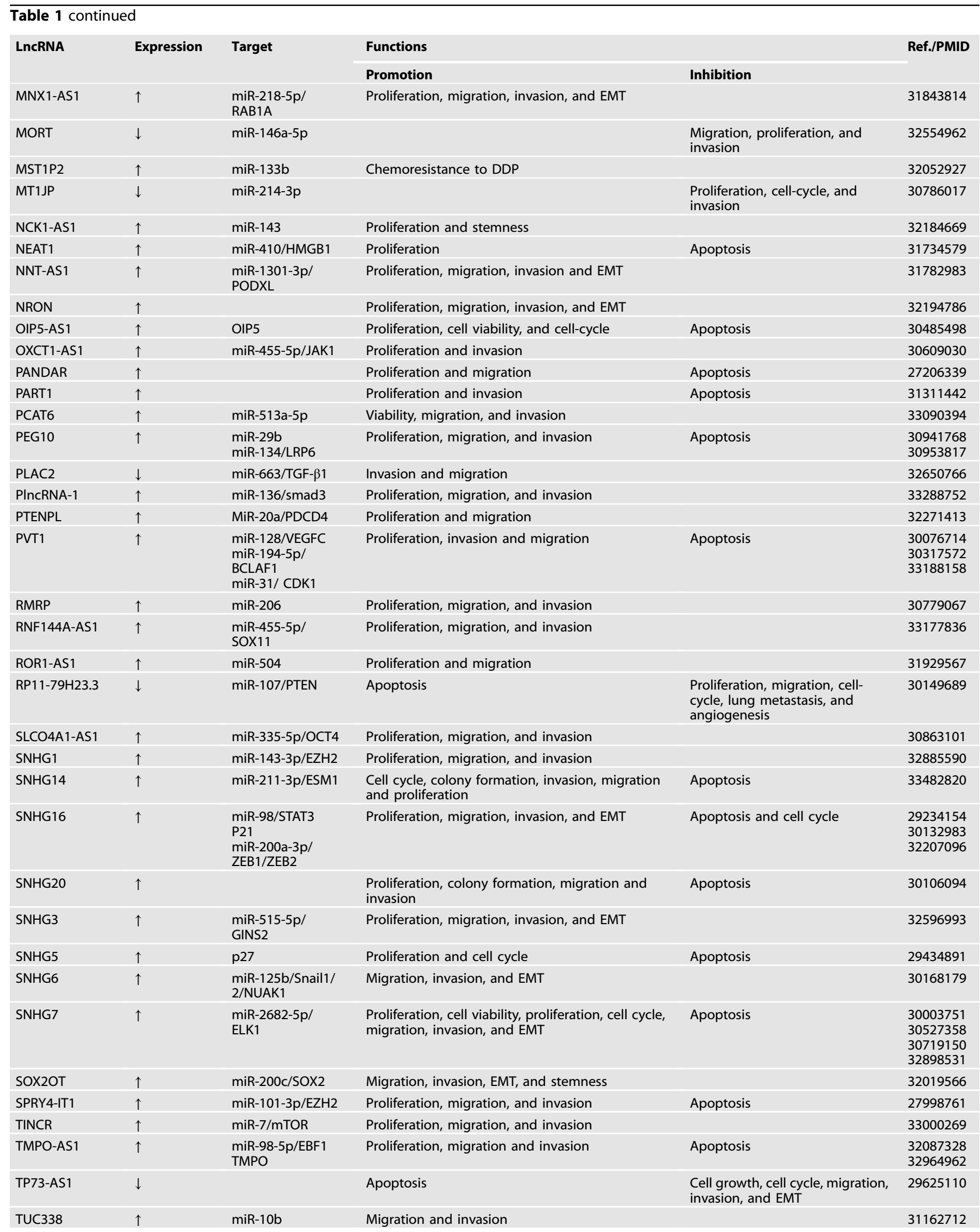


Table 1 continued

\begin{tabular}{|c|c|c|c|c|c|}
\hline \multirow[t]{2}{*}{ LncRNA } & \multirow[t]{2}{*}{ Expression } & \multirow[t]{2}{*}{ Target } & \multicolumn{2}{|l|}{ Functions } & \multirow[t]{2}{*}{ Ref./PMID } \\
\hline & & & Promotion & Inhibition & \\
\hline TUG1 & $\uparrow$ & $\begin{array}{l}\text { miR-145/miR-142/ } \\
\text { ZEB2 } \\
\text { miR-29c } \\
\text { HMGB1 } \\
\text { miR-194-5p/ } \\
\text { CCND2 } \\
\text { Nrf2 }\end{array}$ & $\begin{array}{l}\text { Proliferation, migration, invasion, cisplatin } \\
\text { resistance, radioresistance, and EMT }\end{array}$ & $\begin{array}{l}\text { Apoptosis, radiosensitivity, and } \\
\text { sensitivity of Adriamycin }\end{array}$ & $\begin{array}{l}26318860 \\
28376901 \\
28503069 \\
29321088 \\
30925453 \\
31308746\end{array}$ \\
\hline ZEB1-AS1 & $\uparrow$ & $\begin{array}{l}\text { miR-200b/FSCN1/ } \\
\text { TGF- } \beta 1 \\
\text { ZEB1/AUF1 }\end{array}$ & Proliferation, migration, invasion, and metastasis & Apoptosis & $\begin{array}{l}30823924 \\
31115480\end{array}$ \\
\hline ZEB2-AS1 & $\uparrow$ & miR-27b & Proliferation & Apoptosis & 28992472 \\
\hline ZFAS1 & $\uparrow$ & $\begin{array}{l}\operatorname{miR}-329 \\
\text { KLF2/NKD2 } \\
\text { ZEB1/ZEB2 }\end{array}$ & $\begin{array}{l}\text { Proliferation, colony formation, cell cycle, } \\
\text { migration, and invasion }\end{array}$ & Apoptosis & $\begin{array}{l}29653362 \\
29678899\end{array}$ \\
\hline ZNF503-AS1 & $\downarrow$ & SLC8A1/GATA6 & $\begin{array}{l}\text { The intracellular } \mathrm{Ca} 2+\text { concentration and cell } \\
\text { apoptosis }\end{array}$ & $\begin{array}{l}\text { Proliferation, invasion and } \\
\text { migration }\end{array}$ & 33001357 \\
\hline ZNFX1-AS1 & $\uparrow$ & $\begin{array}{l}\operatorname{miR}-193 a-3 p / \\
\text { SDC1 }\end{array}$ & $\begin{array}{l}\text { Proliferation, cell clone formation, migration, and } \\
\text { invasion }\end{array}$ & & 32432735 \\
\hline
\end{tabular}

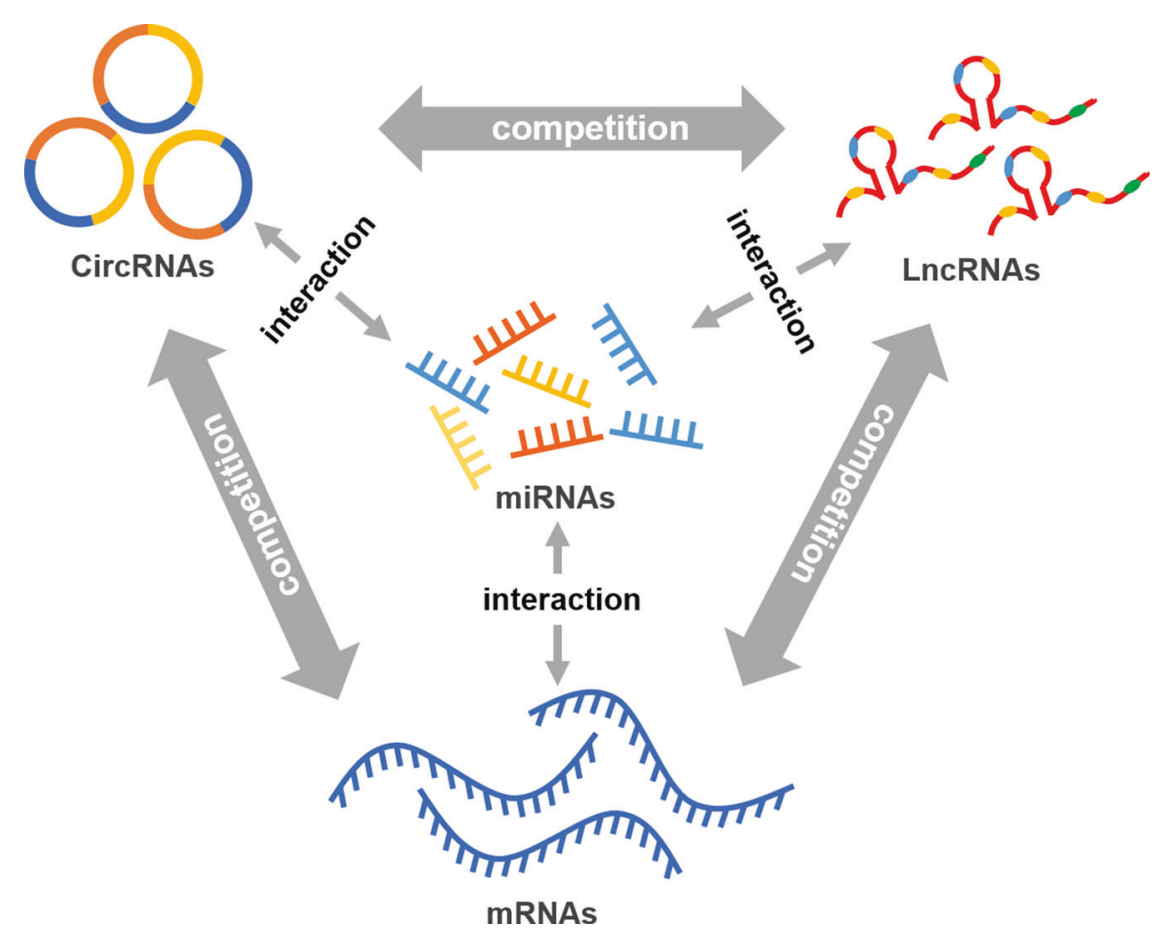

Fig. 1 The overview of the ceRNA hypothesis. 
CRNDE strengthens cell migration and proliferation and inhibits cell apoptosis in BCa [68]. CCAT1 promotes BCa cell proliferation, migration, and invasion [69]. AFAP1-AS1 promotes the proliferation ability and invasiveness of BCa cells [70]. Overexpression of DGCR5 markedly inhibits proliferation and its ectopic expression leads to decreased BCa cell migration, invasion, and EMT, and promotes apoptosis [71].

\section{CELL APOPTOSIS}

Regulated cell death (RCD), also named cell suicide pathways, is of great importance in organismal development, homeostasis, and cancer pathogenesis [72]. Autophagy is an evolutionarily conserved process, in which dysfunctional cellular components are sequestered into lysosomes and degraded [73]. This process maintains cellular energy levels and promotes cellular survival. LncRNAs are reported to modulate autophagy [74]. ADAMTS9-AS2 inhibits BCa progression by affecting several key autophagy and apoptotic proteins [75]. Similarly, a study by Ying et al. demonstrated that insufficient expression of MEG3 could activate autophagy and promote cell proliferation [76]. Another study by Liu et al. showed that lowexpression of MEG3 inhibits apoptosis of BCa by regulating miR-96 along with TPM1 [77]. In contrast, UCA1 targets miR-582-5p and promotes $\mathrm{BCa}$ invasion, migration, growth, and drug resistance through ATG7-mediated autophagy inhibition [78].

Numerous studies indicate that the activity of Wnt/ $\beta$-catenin signaling can either foster or restrain the processes of apoptosis based on specific cellular environmental stimuli [79, 80]. Low TUG1 expression inhibits $\mathrm{BCa}$ cell proliferation and induces apoptosis by promoting ZEB2 mediated miR-142 suppression via inactivation of the $\mathrm{Wnt} / \beta$-catenin pathway [81]. LINC00511 knockdown suppresses the proliferation and promotes apoptosis of $\mathrm{BCa}$ cells by suppressing the activity of the Wnt/ $\mathrm{B}$-catenin signaling pathway [82]. Cao et al. showed that SNHG16 is overexpressed in $\mathrm{BCa}$ tissues and cell lines and can notably promote proliferation by suppressing apoptosis of BCa cells by targeting P21 expression and regulating the miR-98/STAT3/Wnt/ $\beta$-catenin axis $[83,84]$.

Increasing evidence suggests that IncRNAs can affect cell apoptosis by regulating the miRNA-mRNA axis or directly targeting gene expression. As a target of miR-125b, MALAT1 is upregulated in $\mathrm{BCa}$ and inhibits $\mathrm{BCa}$ cell apoptosis by regulating Bcl-2/MMP-13 and SIRT7 $[85,86]$. Another study by Shan et al. showed that NEAT1 inhibits cell apoptosis by regulating miR-410 mediated HMGB1 expression [87]. SNHG14 increases the growth and metastasis of $\mathrm{BCa}$ and inhibits apoptosis by regulating the miR-211-3p/ESM1 axis [88]. LINC00162 can regulate PTTG1IP expression by binding THRAP3 to promote cell proliferation and inhibit apoptosis [89]. Other IncRNAs, such as SNHG7 [90, 91], ANRIL [92], ZEB2-AS1 [93], OIP5-AS1 [94], and PART1 [95], also have the same effects.

\section{INVASION, MIGRATION, AND METASTASIS}

Tumor cells can invade peripheral tissues and spread to the circulatory system or lymphatic system through invasion, migration, and metastasis, leading to the colonization of distant organs [96]. LncRNAs have been reported to play critical regulatory roles in tumor progression. The Wnt/ $\beta$-catenin signaling pathway also plays a crucial role in invasion, migration, and metastasis [79]. LncRNAs promote tumor progression via the $\mathrm{Wnt} / \beta$-catenin signaling pathway. Overexpression of $\mathrm{H} 19$ increases $\mathrm{BCa}$ migration and metastasis by interacting with $\mathrm{EZH} 2$ and downregulating E-cadherin expression through Wnt/ $\beta$-catenin pathway activation [97]. Numerous studies have reported that $\mathrm{H} 19$ functions as a ceRNA that leads to EMT and metastasis of BCa via the miR-29b3p/DNMT3B axis [98]. DLX6-AS1 promotes cell proliferation, invasion, and migration in $\mathrm{BCa}$ by modulating the miR-223/ HSP90B1 and miR-195-5p/VEGFA axes, and the Wnt/B-catenin signaling pathway [99-101]. CASC9 positively regulates FZD6 expression by sponging miR-497-5p and subsequently activates the $\mathrm{Wnt} / \beta$-catenin signaling pathway to promote cell metastasis [102]. Downregulated SNHG7 inhibits cell proliferation and migration in $\mathrm{BCa}$ by regulating the miR-2682-5p/ELK1/Src/FAK axis and activating the $W n t / \beta$-catenin pathway [103, 104]. PEG10 as an oncogene in $\mathrm{BCa}$ facilitates cell growth, migration, and invasion by mediating the miR-29b and miR-134/LRP6 axis to activate the Wnt/ $\beta$-catenin and JAK/STAT or JNK signaling pathways $[105,106]$. PVT1 can regulate the miR-128/VEGFC and miR-194-5p/BCLAF1 axes to promote metastasis by activating the Wnt/ß-catenin pathway [107, 108]. NNT-AS1 enhances cell proliferation, migration, and invasion by regulating the miR1301-3p/PODXL axis and activating the Wnt pathway [109]. SNHG20 promotes cell proliferation, and metastasis by activating the Wnt/ $\beta$-catenin signaling pathway [110]. Some tumor suppressor IncRNAs can inhibit BCa development by the Wnt pathway, such as MIR143HG, which can modulate the miR-1275/AXIN2 axis [111]. LINC00675 regulates $\beta$-catenin expression and is associated with BCa cell migration, invasion, and proliferation [112].

Increasing evidence suggests that ceRNAs play an important role in BCa metastasis mechanisms. ZEB1-AS1 regulates the miR$200 \mathrm{~b} / \mathrm{FSCN} 1$ axis and enhances migration and invasion induced by TGF- $\beta 1$ in BCa cells [113]. Zhao et al. demonstrated that ZEB1-AS1 also induces migration and metastasis via AUF1mediated translation activation of the ZEB1 mRNA mechanism [114]. Silencing of TINCR expression significantly reduces $B C a$ cell proliferation, migration, and invasion by regulating miR-7 and mTOR expression [115]. HOTAIR promotes the proliferation, migration, and invasion of $\mathrm{BCa}$ cells by regulating $\mathrm{CCNJ}$ and inhibiting miRNA-205 [116]. MAFG-AS1 regulates the miR-125b$5 \mathrm{p} / \mathrm{SphK} 1$ and the miR-143-3p/COX-2 axes to promote the proliferation, migration, and invasion of $\mathrm{BCa}$ cells $[117,118]$. SPRY4-IT1 sponges miR-101-3p to promote the proliferation, migration, and invasion of BCa cells by upregulating EZH2 [119]. OXCT1-AS1 promotes cell invasion via the miR-455-5p/JAK1 axis [120]. EGFR-AS1 may promote cell invasion and migration by regulating the miR-381/ ROCK2 axis in $\mathrm{BCa}$ [121]. HCP5 promotes cell invasion and migration by sponging miR-29b-3p and regulating HMGB1 and TLR4 expression [122]. LINC01140 can regulate miR-140-5p/FGF9 axis as ceRNA to modulate the $\mathrm{BCa}$ phenotype, affect macrophage $M 2$ polarization through the tumor microenvironment, and affect BCa cell aggressiveness [123]. In contrast, MAGI2-AS3 and PLAC2 are downregulated in BCa. MAGI2-AS3 can regulate miR-15b-5p/CCDC19 and miR-31-5p/ TNS1 to inhibit proliferation, migration and invasion [124, 125]. PLAC2 suppresses BCa cell metastasis by targeting the miR-663/ TGF- $\beta 1$ axis [126].

ZFAS1 knockdown inhibits cell migration and invasion by downregulating ZEB1/ZEB2 expression [59]. TUC338 promotes metastasis but not the proliferation of $\mathrm{BCa}$ and positive expression of miR-10b [127]. ELF3-AS1 increases the viability and migration of $\mathrm{BCa}$ cells by interacting with KLF8 and increasing MMP9 expression [128]. A higher level of LINC01638 expression promotes the migration and invasion of BCa cells and increases ROCK2 expression [129]. PCAT6 promotes the viability, migration, and invasion of $\mathrm{BCa}$ cells by targeting miR-513a-5p [130]. Low expression of MORT induces cell invasion, migration, and proliferation by upregulating miR-146a-5p [131]. RMRP promotes the proliferation, migration, and invasion of BCa via miR-206 [132]. Other overexpressed IncRNAs, including HNF1A-AS1 [133], PANDAR [134], and LINC00460 [135], can promote the migration and/ or invasion of $\mathrm{BCa}$.

\section{EMT PROCESS}

The EMT process is defined as the transformation process of epithelial cells to mesenchymal cells, providing cells with the 
ability to metastasize and invade. UCA1 regulates the miR-143/ HMGB1 axis, and promotes the invasion and EMT of BCa cells [136]. Similarly, SNHG3 promotes the EMT process through the miR-515-5p/GINS2 axis [137]. ZNRD1-AS1 knockdown inhibits cell metastasis, and EMT of BCa by regulating miR-194/ZEB1 [138]. The EMT process of BCa cells partly relies on SNHG16 via the miR-200a$3 p / Z E B 1 / Z E B 2$ axis [139]. SNHG6 promotes cell metastasis and EMT partly by targeting the miR-125b/Snail1/2/NUAK1 axis [140]. MALAT1 knockdown inhibits TGF-b-induced EMT and is associated with SUZ12 [141]. It also assists tumor growth and metastasis by targeting the miR-124/FOXQ1 axis [142]. MNX1AS1 promotes the proliferation, metastasis, and EMT process of BCa by targeting miR-218-5p/RAB1A expression [143]. LINC00612 enhances BCa cell invasion and EMT by sponging miR-590/PHF14 expression [144]. AC114812.8 promotes cell proliferation, migration, invasion, and EMT through the miR-371b-5p/FUT4 axis [145]. ARSR sponges miR-129-5p to promote proliferation, migration, invasion, and EMT processes by increasing SOX4 expression [146]. LINC01116 increases the expression of ELK3 by adsorbing miR3612 and stabilizes HOXD8 mRNA by binding with DKC1. With the combination of ELK3 and HOXD8, LINC01116 promotes cell proliferation, metastasis, and the EMT process [147].

Furthermore, IncRNAs can also regulate the EMT process via some signaling pathways. CASC9 sponges miR-758-3p/TGF- $\beta 2$ (a key gene of the TGF- $\beta$ signaling pathway) expression to promote proliferation and EMT [148]. LSINCT5 activates Wnt/ $\beta$-catenin signaling by interacting with NCYM to promote the EMT process [149]. CARLo-7 enables the proliferation, metastasis, and EMT of $\mathrm{BCa}$ cells by regulating the Wnt/ $\beta$-catenin and JAK2/ STAT3 signaling pathways [75].

LncRNAs can directly regulate target gene expression and affect the EMT process. Overexpression of MAGI2-AS3 inhibits EMT by regulating the MAGI2/PTEN axis [150]. MIR503HG inhibits cell growth, metastasis, and EMT in BCa [151]. P73-AS1 inhibits cell growth, and cell metastasis, and promotes cell apoptosis. In addition, P73-AS1 blocks the EMT process by inhibiting VIMENTIN, Snail, MMP2, and MMP9 expression and upregulating the expression of E-cadherin [152]. In contrast, MAFG-AS1 promotes proliferation, invasion, metastasis, and EMT via regulation of the HUR/PTBP1 axis [153]. LINC01605 upregulates the expression of matrix MMP9 to promote cell proliferation, migration, and invasion by activating the EMT pathway [154]. LINC01296 [155] and NRON [156] also promote the EMT process in BCa.

\section{ANGIOGENESIS}

Angiogenesis plays a critical role in tumorigenesis and the diffusion of malignant lesions by enhancing nutrient and oxygen supplies as well as providing a conduit for distant metastasis [157]. FAM83H-AS1 binds to c-Myc-mediated ULK3 to activate the Hedgehog signaling pathway, and FAM83H-AS1 knockdown inhibits the expression of CD31 and VEGFA (indicators of angiogenesis), suggesting that FAM83HAS1 promotes growth, metastasis, and angiogenesis of BCa cells through ULK3 upregulation and hedgehog activation [158]. In contrast, downregulation of RP11-79H23.3 led to higher CD31 and S100A4 expression and more microvessels. Moreover, $\mathrm{RP} 11-79 \mathrm{H} 23.3$ can regulate the expression of the miR-107/PTEN axis and activate the PI3K/AKT signaling pathway to contribute to the proliferation, migration, apoptosis, and angiogenesis of BCa cells [159].

\section{CHEMORESISTANCE AND RADIO-RESISTANCE}

As a first-line treatment for $\mathrm{BCa}$ in clinical practice, chemotherapy reduces tumor masses in most patients. However, most patients gradually become unresponsive after multiple treatment cycles and eventually suffer tumor recurrence [160]. Several IncRNAs have been shown to modify the chemotherapy response in $\mathrm{BCa}$.
Cisplatin, a basic drug of first-line treatment for chemotherapy, is shown to significantly improve the prognosis in sensitive patients [161]. As an oncogene, TUG1 induces the expression of EZH2 and directly sponges miR-194-5p. Low levels of miR-194-5p result in increased expression of CCND2, which promotes the chemoresistance of BCa cells to cisplatin [162]. Moreover, TUG1 knockdown enhances the sensitivity of BCa cells to adriamycin [163]. LINC00857 knockdown sensitizes BCa cells to cisplatin, by negatively regulating the target gene LMAN1, indicating that LINC00857 can regulate sensitive patient responses to platinumbased chemotherapy [164]. In cisplatin-resistant BCa cells, a high level of HIF1A-AS2 enhances the expression of HMGA1 to constrain the transcriptional activity of p53 family proteins, which affects cisplatin-induced apoptosis [165]. A previous study reported that DLEU1 enhances cisplatin resistance by competitively regulating miR-99b and restoring the expression of the target gene HS3ST3B1 [166]. Downregulated MALAT1 enhances the cisplatin sensitivity of BCa cells via the miR-101-3p/VEGFC axis [167]. MST1P2 has been found to regulate the miR-133b/SIRT1 axis and suppress the sensitivity of BCa cells to cisplatin [168]. UCA1 decreases the cisplatin sensitivity of $\mathrm{BCa}$ cells by enhancing the expression of Wnt6 [169]. IncRNAs can also inhibit drug resistance and promote the chemosensitivity of $\mathrm{BCa}$ cells to cisplatin. For example, overexpression of MEG3 sensitizes BCa cells to the chemotherapy drug cisplatin [170].

Gemcitabine is another cytotoxic chemotherapeutic agent of BCa cells, but the majority of patients, similar to those treated with cisplatin, ultimately experience tumor recurrence [171]. The upregulation of LET hinders BCa recurrence when treating with gemcitabine. However, the proinflammatory cytokine TGF $\beta 1$ can directly decrease LET expression levels in gemcitabine-resistant patients [172]. However, FOXD2-AS1 positively regulates ABCC3 protein via miR-143 targeting, and its knockdown suppresses the $50 \%$ inhibitory concentration of gemcitabine, the expression of drug resistance-related genes (MDR1, MRP2, LRP1), invasion, and $A B C C 3$ protein expression in gemcitabine-resistant BCa cells [173]. High-expression levels of CDKN2B-AS are related to low gemcitabine sensitivity, and downregulated CDKN2B-AS gene levels inactivate the Wnt signaling pathway and ultimately affect the sensitivity of BCa cells to gemcitabine [174]. Similarly, the high expression of GHET1 is associated with low gemcitabine sensitivity in BCa patients, and knockdown of GHET1 advances gemcitabineinduced cytotoxicity [175]. In addition, UCA1 activates the transcription factor CREB, by binding with its promoter and leading to miR-196a-5p expression, while knockdown of UCA1 decreases chemosensitivity to cisplatin/gemcitabine by inhibiting BCa cell growth [176].

More investigations have revealed that IncRNAs also play an important role in chemosensitivity to doxorubicin in BCa. HOTAIR overexpression promotes cell proliferation and inhibits chemosensitivity to doxorubicin, while cell apoptosis is induced by doxorubicin, and GAS5 enhancement reduces chemotherapy resistance to doxorubicin $[177,178]$.

For the radioresistance of $B C a$, the miR-145/ZEB2 axis mediates TUG1 function in EMT and radioresistance, and TUG1 downregulating increases radiosensitivity in $\mathrm{BCa}$ by inhibiting the targeting gene HMGB1 [179, 180].

\section{BCA STEM CELLS}

Although both cancer stem cells (CSCs) and normal tissue stem cells possess the abilities to undergo self-renewal and differentiation, self-renewal is typically deregulated in CSCs [181]. LncRNAs have been reported to regulate cellular identity and differentiation in cancer. Depletion of ASAP1-IT1 in T24 cells reduces the CD44 population, whereas forced overexpression of ASAP1-IT1 in J82 cells enhances cancer cell stemness, suggesting that ASAP1-IT1 is sufficient and necessary for the 
Table 2. Relationship between LncRNAs level and clinicopathologic characteristics in BCa.

\begin{tabular}{|c|c|c|c|c|c|c|c|c|c|c|}
\hline Year & Author & LncRNA & Expression & Sample & Age & Tumor size & Grade & TMN & Stage & Ref./PMID \\
\hline 2013 & Han et al. & MALAT1 & $\uparrow$ & 27 & & & $\sqrt{ }$ & & $\sqrt{ }$ & 24512851 \\
\hline 2015 & Chen et al. & n336928 & $\uparrow$ & 95 & & & $\sqrt{ }$ & & $\checkmark$ & 26551459 \\
\hline 2016 & Zhan et al. & PANDAR & $\uparrow$ & 55 & & & $\sqrt{ }$ & $\checkmark$ & & 27206339 \\
\hline 2016 & Qi et al. & DBCCR1-003 & $\downarrow$ & 24 & & & $\sqrt{ }$ & & & 27777512 \\
\hline 2017 & Zhang et al. & GAS5 & $\downarrow$ & 82 & & & $\sqrt{ }$ & & & 27878359 \\
\hline 2017 & Lv et al. & $\mathrm{H} 19$ & $\uparrow$ & 35 & & & & $\checkmark$ & & 28779971 \\
\hline 2017 & Yang et al. & ASAP1-IT1 & $\uparrow$ & 58 & & & & $\checkmark$ & & 28895409 \\
\hline 2017 & Wang et al. & HULC & $\uparrow$ & 276 & & & & & $\checkmark$ & 28946549 \\
\hline 2017 & Wu et al. & ZEB2-AS1 & $\uparrow$ & 52 & & $\checkmark$ & & v & $\checkmark$ & 28992472 \\
\hline 2017 & Cao et al. & SNHG16 & $\uparrow$ & 46 & & & & $\checkmark$ & $\checkmark$ & 29234154 \\
\hline 2018 & Li et al. & CASC2a & $\downarrow$ & 112 & & $\checkmark$ & & $\checkmark$ & & 29358570 \\
\hline 2018 & Yang et al. & ZFAS1 & $\uparrow$ & 102 & & & & $\checkmark$ & $\sqrt{ }$ & 29678899 \\
\hline 2018 & Cheng et al. & CRNDE & $\uparrow$ & 54 & & & & $\checkmark$ & & 29710461 \\
\hline 2018 & Jiao et al. & MALAT1 & $\uparrow$ & 56 & & & & & $\sqrt{ }$ & 29736319 \\
\hline 2018 & Wang et al. & HNF1A-AS1 & $\uparrow$ & 191 & & & $\sqrt{ }$ & $\checkmark$ & & 29762827 \\
\hline 2018 & Zhu et al. & LSINCT5 & $\uparrow$ & 108 & & $\checkmark$ & & $\checkmark$ & & 29772237 \\
\hline 2018 & Xie et al. & CDKN2B-AS1 & $\uparrow$ & 81 & & & $\sqrt{ }$ & & & 29937935 \\
\hline 2018 & Zhong et al. & SNHG7 & $\uparrow$ & 134 & & $\checkmark$ & & $\checkmark$ & $\sqrt{ }$ & 30003751 \\
\hline 2018 & Qin et al. & LINC01605 & $\uparrow$ & 92 & & & $\sqrt{ }$ & & $\sqrt{ }$ & 30054424 \\
\hline 2018 & Zhao et al. & SNHG2O & $\uparrow$ & 54 & & & & $\checkmark$ & & 30106094 \\
\hline 2018 & Liu et al. & n346372 & $\uparrow$ & 60 & & & $\checkmark$ & & $\checkmark$ & 30365104 \\
\hline 2018 & Avgeris et al. & GAS5 & $\downarrow$ & 363 & & & $\checkmark$ & & & 30374124 \\
\hline 2018 & Qiu et al. & MIR503HG & $\downarrow$ & 70 & & & $\checkmark$ & $\checkmark$ & $\checkmark$ & 30672010 \\
\hline 2019 & Chen et al. & SNHG7 & $\uparrow$ & 92 & & $\checkmark$ & & $\checkmark$ & $\sqrt{ }$ & 30527358 \\
\hline 2019 & Guo et al. & ELF3-AS1 & $\uparrow$ & 102 & & & & $\checkmark$ & & 30528231 \\
\hline 2019 & Wang et al. & LINC01296 & $\uparrow$ & 78 & & & $\sqrt{ }$ & $\checkmark$ & $\checkmark$ & 30588032 \\
\hline 2019 & Xu et al. & SNHG7 & $\uparrow$ & 72 & & & $\sqrt{ }$ & $\checkmark$ & & 30719150 \\
\hline 2019 & Cao et al. & RMRP & $\uparrow$ & 91 & & $\checkmark$ & & $\checkmark$ & & 30779067 \\
\hline 2019 & Yang et al. & SLCO4A1-AS1 & $\uparrow$ & 58 & & & & $\checkmark$ & $\checkmark$ & 30863101 \\
\hline 2019 & Yu et al. & TUG1 & $\uparrow$ & 87 & & & & $\checkmark$ & & 30925453 \\
\hline 2019 & Zhang et al. & CCAT1 & $\uparrow$ & 34 & & $\checkmark$ & $\checkmark$ & & $\checkmark$ & 31038865 \\
\hline 2019 & Li et al. & GHET1 & $\uparrow$ & 74 & & & $\checkmark$ & $\checkmark$ & & 31115606 \\
\hline 2019 & Zhuang et al. & GClnc1 & $\uparrow$ & 60 & & & & $\checkmark$ & & 31298933 \\
\hline 2019 & Jiang et al. & HCG22 & $\downarrow$ & 78 & & $\checkmark$ & & $\checkmark$ & $\checkmark$ & 31304601 \\
\hline 2019 & Dai et al. & ITGB1 & $\uparrow$ & 36 & & & & & $\checkmark$ & 31486485 \\
\hline 2019 & Zhou et al. & XIST & $\uparrow$ & 52 & & & & $\checkmark$ & & 31602223 \\
\hline 2019 & Yang et al. & LINC00319 & $\uparrow$ & 47 & & & & & $\checkmark$ & 31608995 \\
\hline 2019 & Wei et al. & MBNL1-AS1 & $\downarrow$ & 21 & & $\checkmark$ & & & $\checkmark$ & 31769229 \\
\hline 2020 & Liao et al. & ARSR & $\uparrow$ & 62 & & $\checkmark$ & $\checkmark$ & & & 31892841 \\
\hline 2020 & Chen et al. & ROR1-AS1 & $\uparrow$ & 65 & & & $\sqrt{ }$ & $\checkmark$ & $\checkmark$ & 31929567 \\
\hline 2020 & Zhan et al. & SOX2OT & $\uparrow$ & 106 & & & $\checkmark$ & $\checkmark$ & & 32019566 \\
\hline 2020 & Luo et al. & TMPO-AS1 & $\uparrow$ & 40 & & $\checkmark$ & $\sqrt{ }$ & & $\sqrt{ }$ & 32087328 \\
\hline 2020 & Xiong et al. & NRON & $\uparrow$ & 42 & & & & $\sqrt{ }$ & & 32194786 \\
\hline
\end{tabular}


Table 2 continued

\begin{tabular}{|c|c|c|c|c|c|c|c|c|c|c|}
\hline Year & Author & LncRNA & Expression & Sample & Age & Tumor size & Grade & TMN & Stage & Ref./PMID \\
\hline 2020 & Wang et al. & BCAR4 & $\uparrow$ & 38 & & & & $\sqrt{ }$ & $\sqrt{ }$ & 32273720 \\
\hline 2020 & Wu et al. & ZNFX1-AS1 & $\uparrow$ & 67 & & $\checkmark$ & & & $\checkmark$ & 32432735 \\
\hline 2020 & Han et al. & TINCR & $\uparrow$ & 71 & & & $\checkmark$ & $\sqrt{ }$ & & 32622721 \\
\hline 2020 & Li et al. & PVT1 & $\uparrow$ & 98 & & & $\checkmark$ & $\sqrt{ }$ & & 32664121 \\
\hline 2020 & He et al. & RBAT1 & $\uparrow$ & 30 & & & & & $\checkmark$ & 32669100 \\
\hline 2020 & Li et al. & IGFBP4-1 & $\uparrow$ & 100 & & & $\checkmark$ & $\sqrt{ }$ & & 32760196 \\
\hline 2020 & Li et al. & KCNQ1OT1 & $\uparrow$ & 30 & & & $\sqrt{ }$ & $\checkmark$ & & 32820233 \\
\hline 2020 & Xiang et al. & SNHG1 & $\uparrow$ & 60 & & $\checkmark$ & & $\checkmark$ & $\sqrt{ }$ & 32885590 \\
\hline 2020 & Wang et al. & SNHG7 & $\uparrow$ & 60 & & & & & $\sqrt{ }$ & 32898531 \\
\hline 2020 & He et al. & TMPO-AS1 & $\uparrow$ & 40 & & & & $\checkmark$ & & 32964962 \\
\hline 2020 & Gui et al. & AFAP1-AS1 & $\uparrow$ & 40 & & & & $\sqrt{ }$ & & 32964963 \\
\hline 2020 & Zhang et al. & PCAT6 & $\uparrow$ & 106 & & $\checkmark$ & & $\checkmark$ & & 33142195 \\
\hline 2020 & Chen et al. & PVT1 & $\uparrow$ & 70 & & & $\checkmark$ & $\checkmark$ & & 33188158 \\
\hline 2020 & Huang et al. & CARLo-7 & $\uparrow$ & 143 & & & $\checkmark$ & $\sqrt{ }$ & $\checkmark$ & 33209690 \\
\hline 2020 & Tang et al. & MAGI2-AS3 & $\downarrow$ & 45 & & & & $\checkmark$ & & 33231563 \\
\hline 2020 & Li et al. & MAFG-AS1 & $\uparrow$ & 43 & & $\checkmark$ & $\sqrt{ }$ & $\checkmark$ & & 33238264 \\
\hline 2020 & Kang et al. & PlncRNA-1 & $\uparrow$ & 28 & $\checkmark$ & $\checkmark$ & & $\checkmark$ & & 33288752 \\
\hline 2020 & Liu et al. & FAM83H-AS1 & $\uparrow$ & 82 & & & & $\sqrt{ }$ & & 33289601 \\
\hline 2020 & Xiao et al. & MAFG-AS1 & $\uparrow$ & 102 & & & & & $\sqrt{ }$ & 33377647 \\
\hline 2021 & Zhang et al. & CASC9 & $\uparrow$ & 49 & $\checkmark$ & & & $v$ & & 33200222 \\
\hline 2021 & Feng et al. & SNHG14 & $\uparrow$ & 62 & & & & $\sqrt{ }$ & $\sqrt{ }$ & 33482820 \\
\hline
\end{tabular}

maintenance of stemness [182]. Overexpression of NCK1-AS1 reduces miR-143 expression and promotes proliferation and increases CD133 expression [183]. HOXA-AS2 is upregulated in $B C a$ cells and Wang et al. reported that it is positively correlated with the expression of OCT4. In addition, HOXA-AS2 promotes the migration, invasion, and stemness of BCa cells [184]. SOX2OT is highly expressed in $\mathrm{BCa}$, upregulates SOX2 expression by sponging miR-200c, and downregulates SOX2OT to inhibit BCSC self-renewal, cell migration, invasion, and EMT [185]. LBCS can inhibit BCSC self-renewal and chemoresistance by suppressing SOX2 expression [186].

\section{LNCRNAS ARE ASSOCIATED WITH CLINICOPATHOLOGICAL CHARACTERISTICS}

Numerous reports show that IncRNAs have two main functions in promoting or inhibiting tumor development. Further analysis has shown that IncRNAs are closely related to many clinicopathological characteristics, such as stage, tumor size, and grade (Table 2).

The risk of tumor development in $\mathrm{BCa}$ varies according to the patient's age and sex [187]. Interestingly, IncRNAs have no relationship with patient sex, while two studies have reported that CASC9 and PIncRNA-1 are associated with patient age. CASC9 upregulation is significantly positively correlated with $\mathrm{BCa}$ tumor invasion depth, histological grade, and age; however, sex and tumor volume were not related to CASC9 expression levels [62, 102, 148].

For BCa tumor size, several IncRNAs are related. The high expression level of ZNFX1-AS1 is related to advanced clinical stages and tumor size [47]. High expression of ZEB2-AS1 and SNHG5 is significantly correlated with tumor size, lymph node metastasis, and clinical stage [60,93]. Patients with advanced- stage disease have higher levels of OIP5-AS1 expression than those with early-stage disease. High OIP5-AS1 expression is also observed in muscular invasion or large tumors [94]. Similarly, increased SNHG1 expression is closely correlated with tumor size, stage, invasion, and metastasis [188]. CCAT1 is positively related to clinical stage, tumor grade, and tumor size [69]. Increased ARSR expression is positively correlated with higher histological grade and larger tumor size [146]. SNHG3 [137], RMRP [132], PCAT6 [189], and LSINCT5 [149] expression positively correlated with tumor size and TNM stage, while high expression of MAFG-AS1 [118, 153], SNHG7 [90, 103], and TMPO-AS1 [33, 34] was closely related to histological grade, tumor size, TNM stage, and clinical stage of $\mathrm{BCa}$ patients. However, many IncRNAs are important for tumor size suppression. CASC2a is highly negatively correlated with pathological T and N stages, and tumor size [190]. HCG22 expression correlates with pathological stage, metastasis, and a large tumor range [26]. The MBNL1-AS1 expression level correlates with the clinical stage, tumor size, and focal classification [55]. In addition, downregulated MAGI2-AS3 correlates with the number of tumors, stage, grade, and stage $[125,150]$.

Accumulating evidence has revealed that the TNM stage, grade, and clinical/pathological stage of $\mathrm{BCa}$ can reflect the status of tumor development. High expression of HOTAIR and CDKN2B-AS is associated with a worse tumor grade. In addition, high expression of 5 IncRNAs positively correlates with tumor stage $[21,23,37,53,54]$, while higher expression of 11 other IncRNAs is related to worse TNM stage $[52,61,68,70,98,110,128$, $156,162,182]$. The expression of 4 IncRNAs is positively associated with an advanced disease stage and poor tumor grade $[85,154,191]$. Higher expression levels of 6 IncRNAs are associated with high tumor grade and advanced TNM stage 
Table 3. The relationship between LncRNA and prognosis.

\begin{tabular}{|c|c|c|c|c|c|c|c|}
\hline LncRNA & Expression & Prognostic & OS & PFS & DFS & RFS & Ref./PMID \\
\hline CASC2a & $\downarrow$ & $\sqrt{ }$ & & & & $\sqrt{ }$ & 29358570 \\
\hline DGCR5 & $\downarrow$ & $\checkmark$ & & & & & 30238982 \\
\hline GAS5 & $\downarrow$ & $\sqrt{ }$ & & $\sqrt{ }$ & & & $\begin{array}{l}27878359 \\
30374124\end{array}$ \\
\hline HCG18 & $\downarrow$ & $\checkmark$ & $\sqrt{ }$ & & & & 30426533 \\
\hline HCG22 & $\downarrow$ & $\checkmark$ & $\checkmark$ & & & & 31304601 \\
\hline LINC00675 & $\downarrow$ & $\checkmark$ & & & & & 32367602 \\
\hline MAGI2-AS3 & $\downarrow$ & $\sqrt{ }$ & $\sqrt{ }$ & & & & $\begin{array}{l}30442369 \\
33104021\end{array}$ \\
\hline MIR143HG & $\downarrow$ & $\checkmark$ & & & & & 30471109 \\
\hline PLAC2 & $\downarrow$ & $\checkmark$ & $\sqrt{ }$ & & & & 32650766 \\
\hline ASAP1-IT1 & $\uparrow$ & $\checkmark$ & & & & & 28895409 \\
\hline BCAR4 & $\uparrow$ & $\checkmark$ & $\sqrt{ }$ & & & & 32273720 \\
\hline CALML3-AS1 & $\uparrow$ & $\sqrt{ }$ & $\sqrt{ }$ & $\sqrt{ }$ & & & 30177388 \\
\hline CASC9 & $\uparrow$ & $\checkmark$ & & & $\sqrt{ }$ & & $\begin{array}{l}32677984 \\
33200222\end{array}$ \\
\hline DLEU1 & $\uparrow$ & $\checkmark$ & & & & & 30984249 \\
\hline DLX6-AS1 & $\uparrow$ & $\sqrt{ }$ & $\sqrt{ }$ & & & & $\begin{array}{l}31615303 \\
32756011\end{array}$ \\
\hline EGFR-AS1 & $\uparrow$ & $\checkmark$ & $\sqrt{ }$ & & & & 32194685 \\
\hline ELF3-AS1 & $\uparrow$ & $\checkmark$ & $\sqrt{ }$ & & & & 30528231 \\
\hline FAM83H-AS1 & $\uparrow$ & $\sqrt{ }$ & $\sqrt{ }$ & & & & $\begin{array}{l}30537032 \\
33289601\end{array}$ \\
\hline IGFBP4-1 & $\uparrow$ & $\sqrt{ }$ & $\sqrt{ }$ & & & & 32760196 \\
\hline ITGB1 & $\uparrow$ & $\checkmark$ & $\sqrt{ }$ & & & & 31486485 \\
\hline LINC00162 & $\uparrow$ & $\checkmark$ & & & & & 33344916 \\
\hline LINC00319 & $\uparrow$ & $\checkmark$ & & & & $\sqrt{ }$ & $\begin{array}{l}31608995 \\
32194636\end{array}$ \\
\hline LINC00460 & $\uparrow$ & $\checkmark$ & & & & & 30881506 \\
\hline LINC00857 & $\uparrow$ & $\sqrt{ }$ & $\sqrt{ }$ & & & $\sqrt{ }$ & 29856124 \\
\hline LINC01140 & $\uparrow$ & $\sqrt{ }$ & $\sqrt{ }$ & & & & 33234721 \\
\hline LINC01296 & $\uparrow$ & $\sqrt{ }$ & $\sqrt{ }$ & & & & 30588032 \\
\hline LINC01605 & $\uparrow$ & $\checkmark$ & & & & & 30054424 \\
\hline ARSR & $\uparrow$ & $\checkmark$ & $\sqrt{ }$ & & & $\sqrt{ }$ & 31892841 \\
\hline n336928 & $\uparrow$ & $\checkmark$ & $\checkmark$ & & & & 26551459 \\
\hline LSINCT5 & $\uparrow$ & $\checkmark$ & & & & & 29772237 \\
\hline MAFG-AS1 & $\uparrow$ & $\checkmark$ & $\sqrt{ }$ & & & & $\begin{array}{l}33238264 \\
33377647 \\
33400245\end{array}$ \\
\hline MALAT1 & $\uparrow$ & $\checkmark$ & $\sqrt{ }$ & & & & $\begin{array}{l}24449823 \\
29736319\end{array}$ \\
\hline n346372 & $\uparrow$ & $\checkmark$ & & & & & 30365104 \\
\hline NCK1-AS1 & $\uparrow$ & $\sqrt{ }$ & & & & & 32184669 \\
\hline NRON & $\uparrow$ & $\sqrt{ }$ & $\sqrt{ }$ & & & $\sqrt{ }$ & 32194786 \\
\hline
\end{tabular}


Table 3 continued

\begin{tabular}{|c|c|c|c|c|c|c|c|}
\hline LncRNA & Expression & Prognostic & os & PFS & DFS & RFS & Ref./PMID \\
\hline OIP5-AS1 & $\uparrow$ & $\sqrt{ }$ & $\sqrt{ }$ & & & & 30485498 \\
\hline PCAT6 & $\uparrow$ & $\sqrt{ }$ & $\sqrt{ }$ & $\sqrt{ }$ & & & $\begin{array}{l}33090394 \\
33142195\end{array}$ \\
\hline RMRP & $\uparrow$ & $\sqrt{ }$ & & & & & 30779067 \\
\hline RNF144A-AS1 & $\uparrow$ & $\sqrt{ }$ & & & & & 33177836 \\
\hline SNHG1 & $\uparrow$ & $\sqrt{ }$ & & & & $\sqrt{ }$ & 32885590 \\
\hline SNHG14 & $\uparrow$ & $\sqrt{ }$ & & & & & 33482820 \\
\hline SNHG16 & $\uparrow$ & $\sqrt{ }$ & $\sqrt{ }$ & & & & 29234154 \\
\hline SNHG2O & $\uparrow$ & $\sqrt{ }$ & & & & & 30106094 \\
\hline SNHG3 & $\uparrow$ & $\sqrt{ }$ & $\sqrt{ }$ & & $\checkmark$ & & 32596993 \\
\hline SOX2OT & $\uparrow$ & $\sqrt{ }$ & $\sqrt{ }$ & & $\sqrt{ }$ & & 32019566 \\
\hline TINCR & $\uparrow$ & $\sqrt{ }$ & & & & $\sqrt{ }$ & $\begin{array}{l}32622721 \\
33000269\end{array}$ \\
\hline TMPO-AS1 & $\uparrow$ & $\sqrt{ }$ & & & & & $\begin{array}{l}32087328 \\
32964962\end{array}$ \\
\hline TUG1 & $\uparrow$ & $\checkmark$ & $\sqrt{ }$ & & & & $\begin{array}{l}26318860 \\
30925453\end{array}$ \\
\hline XIST & $\uparrow$ & $\checkmark$ & & & & & 31602223 \\
\hline ZFAS1 & $\uparrow$ & $\sqrt{ }$ & $\sqrt{ }$ & $\sqrt{ }$ & & & 29653362 \\
\hline
\end{tabular}

$[42,108,134,185,192,193]$, while some other 4 IncRNAs are significantly correlated with $\mathrm{T}$ stage or metastasis, in addition to tumor grade $[27,36,119,175]$. The expression level of 4 IncRNAs positively correlates with tumor progression stage and TNM stage $[59,88,184,194]$. The expression of SNHG16 [83], BCAR4 [32], and SLCO4A1-AS1 [45] is related to metastasis and pathological stage. In addition, the high expression levels of LINC01296 [155], Carlo-7 [75], and ROR1-AS1 [54] are correlated with advanced tumor stage, higher tumor grade, and metastasis. In contrast, the expression of MIR143HG and MIR503HG is negatively correlated with tumor grade, advanced stage, and lymph node metastasis $[111,151]$. Decreased expression of GAS5 [195] and DBCCR1-003 [196] is observed in BCa patients with higher grades, while LINC00675 [112] expression is decreased in lymph node-metastatic MIBC tissues compared to those without lymph node metastasis. Decreased expression of other IncRNAs, such as LBCS [186], MEG3 [77], and TP73-AS1 [152], is strongly associated with tumor stage, grade, and/or TNM stage.

\section{LNCRNAS THAT INFLUENCE PATIENT PROGNOSIS}

Some IncRNAs can be used to predict patient prognoses, such as overall survival (OS), disease-free survival (DFS), recurrence-free survival (RFS), and progression-free survival (PFS). Here, we reviewed the survival data from studies relating to $\mathrm{BCa}$ to determine the prognostic value of IncRNAs, in terms of OS, DFS, RFS, and PFS. In the last 10 years, more than 60 IncRNAs with the potential to predict patient prognosis have been reported (Table 3). Among them, 3 IncRNAs downregulated in BCa have been found to predict poor PFS $[24,152,195]$, whereas 4 IncRNAs upregulated in BCa predict poor PFS [23, 40,50, 189]. The results of prognosis analysis revealed that high expression of CASC9 [102, 148], SNHG3 [137], and SOX2OT [185], and low expression of LBCS [186] predict poor DFS. Elsewhere, high expression of CASC2a [190] increased the 5-year RFS rate, and high expression of 8 IncRNAs predicted a low RFS rate $[21,23,37,38,115,146,156,164,188,193]$. In addition, lower expression of 7 IncRNAs predicted shorter OS [24, 26, 57, $126,150,152,186]$. High expression of 28 IncRNAs predicted shorter OS $[23,27,32,39,40,45,50,53,60,83,94,100,118$, $121,123,128,130,137,141,146,155,156,162,164,185,192,194$, 197].

\section{CONCLUSION}

Researchers have already found that more than hundreds of IncRNAs could affect the initiation and progression of BCa. In the past 10 years, several biological functions of IncRNAs have been reported, especially in the past two years. As described in this review, more than 100 IncRNAs influence the proliferation, apoptosis, invasion, migration, metastasis, drug resistance, and even CSCs in BCa. Other BCa-related IncRNAs can act as ceRNA regulatory mechanisms to regulate various processes in tumors (Fig. 2). The studies reviewed here also indicate that IncRNAs are strongly associated with $\mathrm{BCa}$ patients' clinicopathological characteristics and prognosis, demonstrating that IncRNAs may be potential diagnostic and prognostic biomarkers for BCa patients.

Several questions remain regarding the role of IncRNAs in $\mathrm{BCa}$. Evidence indicates that one IncRNA can regulate more than one gene. The relationship between such genes should be further investigated. Apart from acting as miRNA sponges and via ceRNA mechanisms, other important mechanisms, such as ubiquitination and other posttranscriptional modifications, should be studied. Moreover, clinical studies with a large sample should be designed to explore the roles of IncRNAs in BCa from the perspectives of epigenetics and posttranscription. In addition, multicenter cohort 


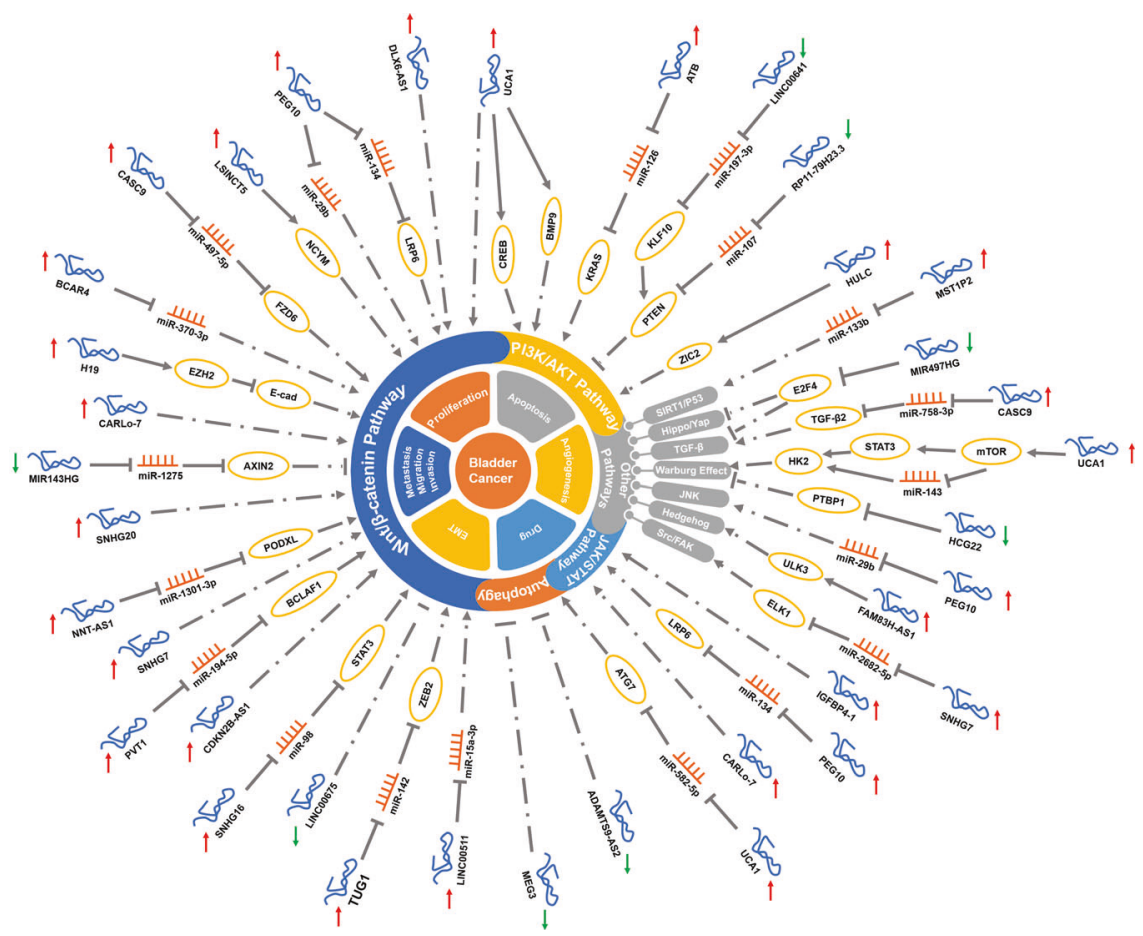

Fig. 2 The detailed mechanisms of IncRNAs on tumor classic pathways in BCa.

studies are necessary to validate the diagnostic, prognostic and therapeutic value of IncRNAs in BCa.

\section{DATA AVAILABILITY}

All data generated or analyzed during this study are included in this published article.

\section{REFERENCES}

1. Bray F, Ferlay J, Soerjomataram I, Siegel RL, Torre LA, Jemal A. Global cancer statistics 2018: GLOBOCAN estimates of incidence and mortality worldwide for 36 cancers in 185 countries. CA Cancer J. Clin. 2018;68:394-424. https://doi.org/ 10.3322/caac.21492.

2. Li Y, Li G, Guo X, Yao H, Wang G, Li C. Non-coding RNA in bladder cancer. Cancer Lett. 2020;485:38-44. https://doi.org/10.1016/j.canlet.2020.04.023.

3. Cumberbatch MGK, Noon AP. Epidemiology, aetiology and screening of bladder cancer. Transl. Androl. Urol. 2019;8:5-11. https://doi.org/10.21037/tau.2018.09.11.

4. Kamat AM, Hahn NM, Efstathiou JA, Lerner SP, Malmstrom PU, Choi W, et al. Bladder cancer. Lancet. 2016;388:2796-810. https://doi.org/10.1016/S0140-6736 (16)30512-8.

5. Yang $X, Y e T$, Liu H, Lv P, Duan C, Wu X, et al. Expression profiles, biological functions and clinical significance of circRNAs in bladder cancer. Mol Cancer. 2021;20:4. https://doi.org/10.1186/s12943-020-01300-8.

6. Cancer Genome Atlas Research N, Weinstein JN, Collisson EA, Mills GB, Shaw KR, Ozenberger BA, et al. The Cancer Genome Atlas Pan-Cancer analysis project. Nat Genet. 2013;45:1113-20. https://doi.org/10.1038/ng.2764.

7. Consortium EP. An integrated encyclopedia of DNA elements in the human genome. Nature. 2012;489:57-74. https://doi.org/10.1038/nature11247.

8. Djebali S, Davis CA, Merkel A, Dobin A, Lassmann T, Mortazavi A, et al. Landscape of transcription in human cells. Nature. 2012;489:101-8. https://doi.org/ 10.1038/nature11233.

9. Chen S, Shen X. Long noncoding RNAs: functions and mechanisms in colon cancer. Mol Cancer. 2020;19:167. https://doi.org/10.1186/s12943-020-01287-2.

10. Prensner JR, Chinnaiyan AM. The emergence of IncRNAs in cancer biology. Cancer Discov. 2011;1:391-407. https://doi.org/10.1158/2159-8290. CD-11-0209.

11. Gibb EA, Brown CJ, Lam WL. The functional role of long non-coding RNA in human carcinomas. Mol Cancer. 2011;10:38. https://doi.org/10.1186/14764598-10-38.

12. Hanahan D, Weinberg RA. Hallmarks of cancer: the next generation. Cell. 2011;144:646-74. https://doi.org/10.1016/j.cell.2011.02.013.
13. Xue M, Chen W, Xiang A, Wang R, Chen H, Pan J, et al. Hypoxic exosomes facilitate bladder tumor growth and development through transferring long non-coding RNA-UCA1. Mol Cancer. 2017;16:143. https://doi.org/10.1186/ s12943-017-0714-8.

14. Wang $X$, Gong $Y$, Jin B, Wu C, Yang J, Wang L, et al. Long non-coding RNA urothelial carcinoma associated 1 induces cell replication by inhibiting BRG1 in 5637 cells. Oncol Rep. 2014;32:1281-90. https://doi.org/10.3892/or.2014.3309.

15. Xue M, Li X, Wu W, Zhang S, Wu S, Li Z, et al. Upregulation of long non-coding RNA urothelial carcinoma associated 1 by CCAAT/enhancer binding protein alpha contributes to bladder cancer cell growth and reduced apoptosis. Oncol Rep. 2014;31:1993-2000. https://doi.org/10.3892/or.2014.3092.

16. Li HJ, Li X, Pang H, Pan JJ, Xie XJ, Chen W. Long non-coding RNA UCA1 promotes glutamine metabolism by targeting miR-16 in human bladder cancer. Jpn J Clin Oncol. 2015;45:1055-63. https://doi.org/10.1093/jjco/hyv132.

17. Li Z, Li X, Wu S, Xue M, Chen W. Long non-coding RNA UCA1 promotes glycolysis by upregulating hexokinase 2 through the mTOR-STAT3/microRNA143 pathway. Cancer Sci. 2014;105:951-5. https://doi.org/10.1111/cas.12461.

18. Yang C, Li X, Wang Y, Zhao L, Chen W. Long non-coding RNA UCA1 regulated cell cycle distribution via CREB through PI3-K dependent pathway in bladder carcinoma cells. Gene. 2012;496:8-16. https://doi.org/10.1016/j.gene.2012.01.012.

19. Gou L, Liu M, Xia J, Wan Q, Jiang Y. Sun S, et al. BMP9 Promotes the proliferation and migration of bladder cancer cells through up-regulating IncRNA UCA1.Int J Mol Sci. 2018;19. https://doi.org/10.3390/ijms19041116.

20. Hoxhaj G, Manning BD. The PI3K-AKT network at the interface of oncogenic signalling and cancer metabolism. Nat Rev Cancer. 2020;20:74-88. https://doi. org/10.1038/s41568-019-0216-7.

21. Wang J, Ma W, Liu Y. Long non-coding RNA HULC promotes bladder cancer cells proliferation but inhibits apoptosis via regulation of ZIC2 and PI3K/AKT signaling pathway. Cancer Biomark. 2017;20:425-34. https://doi.org/10.3233/CBM-170188.

22. Zhai $X, X u$ W. Long noncoding RNA ATB promotes proliferation, migration, and invasion in bladder cancer by suppressing MicroRNA-126. Oncol Res. 2018;26:1063-72. https://doi.org/10.3727/096504018X15152072098476.

23. Su F, He W, Chen C, Liu M, Liu H, Xue F, et al. The long non-coding RNA FOXD2AS1 promotes bladder cancer progression and recurrence through a positive feedback loop with Akt and E2F1. Cell Death Dis. 2018;9:233. https://doi.org/ 10.1038/s41419-018-0275-9.

24. Li Z, Hong S, Liu Z. LnCRNA LINC00641 predicts prognosis and inhibits bladder cancer progression through miR-197-3p/KLF10/PTEN/PI3K/AKT cascade. Biochem Biophys Res Commun. 2018;503:1825-9. https://doi.org/10.1016/j. bbrc.2018.07.120.

25. Zhu Y, Dai B, Zhang H, Shi G, Shen Y, Ye D. Long non-coding RNA LOC572558 inhibits bladder cancer cell proliferation and tumor growth by regulating the 
AKT-MDM2-p53 signaling axis. Cancer Lett. 2016;380:369-74. https://doi.org/ 10.1016/j.canlet.2016.04.030.

26. Jiang D, Zhang Y, Yang L, Lu W, Mai L, Guo H, et al. Long noncoding RNA HCG22 suppresses proliferation and metastasis of bladder cancer cells by regulation of PTBP1. J Cell Physiol. 2020;235:1711-22. https://doi.org/10.1002/ jcp.29090.

27. Li C, Cao Y, Zhang L, Li J, Wu H, Ling F, et al. LncRNA IGFBP4-1 promotes tumor development by activating Janus kinase-signal transducer and activator of transcription pathway in bladder urothelial carcinoma. Int J Biol Sci. 2020;16:2271-82. https://doi.org/10.7150/ijbs.46986.

28. Zhuang C, Liu Y, Fu S, Yuan C, Luo J, Huang $X$, et al. Silencing of IncRNA MIR497HG via CRISPR/Cas13d induces bladder cancer progression through promoting the crosstalk between Hippo/Yap and TGF-beta/Smad signaling. Front Mol Biosci. 2020;7:616768. https://doi.org/10.3389/fmolb.2020.616768.

29. Zhang G, Li S, Lu J, Ge Y, Wang Q, Ma G, et al. LncRNA MT1JP functions as a ceRNA in regulating FBXW7 through competitively binding to miR-92a-3p in gastric cancer. Mol Cancer. 2018;17:87. https://doi.org/10.1186/s12943-0180829-6.

30. Thomson DW, Dinger ME. Endogenous microRNA sponges: evidence and controversy. Nat Rev Genet. 2016;17:272-83. https://doi.org/10.1038/nrg.2016.20.

31. Zhang R, Wang J, Jia E, Zhang J, Liu N, Chi C. IncRNA BCAR4 sponges miR3703p to promote bladder cancer progression via Wnt signaling. Int J Mol Med. 2020;45:578-88. https://doi.org/10.3892/ijmm.2019.4444.

32. Wang $\mathrm{X}$, He H, Rui W, Xie X, Wang D, Zhu Y. Long non-coding RNA BCAR4 binds to miR-644a and targets TLX1 to promote the progression of bladder cancer. Onco Targets Ther. 2020;13:2483-90. https://doi.org/10.2147/OTT.S232965.

33. He YC, Bi YG, Jiang L. LncRNA TMPO-AS1 promotes proliferation and migration in bladder cancer. Eur Rev Med Pharm. Sci. 2020;24:8740-6. https://doi.org/ 10.26355/eurrev_202009_22812.

34. Luo $H$, Yang L, Liu C, Wang X, Dong Q, Liu L, et al. TMPO-AS1/miR-98-5p/EBF1 feedback loop contributes to the progression of bladder cancer. Int J Biochem Cell Biol. 2020;122:105702. https://doi.org/10.1016/j.biocel.2020.105702.

35. Wang J, Zhang $\mathrm{H}$, Situ J, Li M, Sun H. KCNQ1OT1 aggravates cell proliferation and migration in bladder cancer through modulating miR-145-5p/PCBP2 axis. Cancer Cell Int. 2019;19:325. https://doi.org/10.1186/s12935-019-1039-z.

36. Li Y, Shi B, Dong F, Zhu X, Liu B, Liu Y. LncRNA KCNQ1OT1 facilitates the progression of bladder cancer by targeting MiR-218-5p/HS3ST3B1. Cancer Gene Ther. 2020. https://doi.org/10.1038/s41417-020-00211-6.

37. Yang $\mathrm{Y}$, Zhang $\mathrm{F}$, Huang $\mathrm{H}$, Xie $\mathrm{Z}$, Huang $\mathrm{W}$, Xie $\mathrm{H}$, et al. Long noncoding RNA LINC00319 regulates ROMO1 expression and promotes bladder cancer progression via miR-4492/ROMO1 axis. J Cell Physiol. 2020;235:3768-75. https://doi. org/10.1002/jcp.29271.

38. Wang X, Meng R, Hu QM. LINC00319-mediated miR-3127 repression enhances bladder cancer progression through upregulation of RAP2A. Front Genet. 2020;11:180. https://doi.org/10.3389/fgene.2020.00180.

39. Teng J, Ai X, Jia Z, Wang K, Guan Y, Guo Y. Long non-coding RNA ARAP1-AS1 promotes the progression of bladder cancer by regulating miR-4735-3p/ NOTCH2 axis. Cancer Biol Ther. 2019;20:552-61. https://doi.org/10.1080/ 15384047.2018.1538613.

40. Wang $\mathrm{F}$, Zu Y, Huang W, Chen $\mathrm{H}$, Xie H, Yang Y. LncRNA CALML3-AS1 promotes tumorigenesis of bladder cancer via regulating ZBTB2 by suppression of microRNA-4316. Biochem Biophys Res Commun. 2018;504:171-6. https://doi. org/10.1016/j.bbrc.2018.08.150.

41. Luo $H, X u C$, Le W, Ge B, Wang T. IncRNA CASC11 promotes cancer cell proliferation in bladder cancer through miRNA-150. J. Cell Biochem. 2019;120:13487-93. https://doi.org/10.1002/jcb.28622.

42. Zhan $Y$, Chen $Z$, Li Y, He A, He S, Gong $Y$, et al. Long non-coding RNA DANCR promotes malignant phenotypes of bladder cancer cells by modulating the miR149/MSI2 axis as a ceRNA. J Exp Clin. Cancer Res. 2018;37:273. https://doi.org/ 10.1186/s13046-018-0921-1.

43. Rui $X$, Wang L, Pan $H$, Gu T, Shao S, Leng J. LncRNA GAS6-AS2 promotes bladder cancer proliferation and metastasis via GAS6-AS2/miR-298/CDK9 axis. J Cell Mol Med. 2019;23:865-76. https://doi.org/10.1111/jcmm.13986.

44. Tian Z, Cao S, Li C, Xu M, Wei H, Yang H, et al. LncRNA PVT1 regulates growth, migration, and invasion of bladder cancer by miR-31/ CDK1. J Cell Physiol. 2019;234:4799-811. https://doi.org/10.1002/jcp.27279.

45. Yang $Y$, Wang $F$, Huang $H$, Zhang $Y$, Xie $H$, Men T. IncRNA SLCO4A1-AS1 promotes growth and invasion of bladder cancer through sponging miR-335-5p to upregulate OCT4. Onco Targets Ther. 2019;12:1351-8. https://doi.org/10.2147/ OTT.S191740.

46. Chen D, Chen J, Gao J, Zhang Y, Ma Y, Wei W, et al. LncRNA DDX11-AS1 promotes bladder cancer occurrence via protecting LAMB3 from downregulation by sponging miR-2355-5p. Cancer Biother Radiopharm. 2020;35:319-28. https://doi.org/10.1089/cbr.2019.3021.
47. Wu JP, Zhang GY, Sun XZ. LncRNA ZNFX1-AS1 targeting miR-193a-3p/SDC1 regulates cell proliferation, migration and invasion of bladder cancer cells. Eur Rev Med Pharm Sci. 2020;24:4719-28. https://doi.org/10.26355/ eurrev_202005 21160.

48. Bi H, Shang Z, Jia C, Wu J, Cui B, Wang Q, et al. LncRNA RNF144A-AS1 promotes bladder cancer progression via RNF144A-AS1/miR-455-5p/SOX11 axis. Onco Targets Ther. 2020;13:11277-88. https://doi.org/10.2147/OTT.S266067.

49. Guo P, Zhang G, Meng J, He Q, Li Z, Guan Y. Upregulation of long noncoding RNA TUG1 promotes bladder cancer cell proliferation, migration, and invasion by inhibiting miR-29c. Oncol Res. 2018;26:1083-91. https://doi.org/10.3727/ $096504018 \times 15152085755247$.

50. Wang JS, Liu QH, Cheng XH, Zhang WY, Jin YC. The long noncoding RNA ZFAS1 facilitates bladder cancer tumorigenesis by sponging miR-329. Biomed Pharmacother. 2018;103:174-81. https://doi.org/10.1016/j.biopha.2018.04.031.

51. Hu B, Shi G, Li Q, Li W, Zhou H. Long noncoding RNA XIST participates in bladder cancer by downregulating p53 via binding to TET1. J Cell Biochem. 2019;120:6330-8. https://doi.org/10.1002/jcb.27920.

52. Zhou K, Yang J, Li X, Chen W. Long non-coding RNA XIST promotes cell proliferation and migration through targeting miR-133a in bladder cancer. Exp Ther Med. 2019;18:3475-83. https://doi.org/10.3892/etm.2019.7960.

53. Dai L, Chai CM, Shen TY, Tian Y, Shang ZQ, Niu YJ. LncRNA ITGB1 promotes the development of bladder cancer through regulating microRNA-10a expression. Eur Rev Med Pharm Sci. 2019;23:6858-67. https://doi.org/10.26355/ eurrev_201908_18725.

54. Chen Q.Fu L, Upregulation of long non-coding RNA ROR1-AS1 promotes cell growth and migration in bladder cancer by regulation of miR-504. PLoS ONE. 2020;15:e0227568. https://doi.org/10.1371/journal.pone.0227568.

55. Wei $X$, Yang $X$, Wang B, Yang $Y$, Fang Z, Yi C, et al. LncRNA MBNL1-AS1 represses cell proliferation and enhances cell apoptosis via targeting miR-135a-5p/ PHLPP2/FOXO1 axis in bladder cancer. Cancer Med. 2020;9:724-36. https://doi. org/10.1002/cam4.2684.

56. Wei X, Wang B, Wang Q, Yang X, Yang Y, Fang Z, et al. MiR-362-5p, which is regulated by long non-coding RNA MBNL1-AS1, promotes the cell proliferation and tumor growth of bladder cancer by targeting QKI. Front Pharm. 2020;11:164. https://doi.org/10.3389/fphar.2020.00164.

57. Xu Z, Huang B, Zhang Q, He X, Wei H, Zhang D. NOTCH1 regulates the proliferation and migration of bladder cancer cells by cooperating with long noncoding RNA HCG18 and microRNA-34c-5p. J Cell Biochem. 2019;120:6596-604. https://doi.org/10.1002/jcb.27954.

58. Yu H, Wang S, Zhu H, Rao D. LncRNA MT1JP functions as a tumor suppressor via regulating miR-214-3p expression in bladder cancer. J Cell Physiol. 2019. https:// doi.org/10.1002/jcp.28274.

59. Yang $H$, Li G, Cheng B, Jiang R. ZFAS1 functions as an oncogenic long noncoding RNA in bladder cancer.Biosci Rep.2018;38. https://doi.org/10.1042/ BSR20180475.

60. Ma Z, Xue S, Zeng B, Qiu D. IncRNA SNHG5 is associated with poor prognosis of bladder cancer and promotes bladder cancer cell proliferation through targeting p27. Oncol Lett. 2018;15:1924-30. https://doi.org/10.3892/ol.2017.7527.

61. Zhuang C, Ma Q, Zhuang C, Ye J, Zhang F, Gui Y. LncRNA GCInc1 promotes proliferation and invasion of bladder cancer through activation of MYC. FASEB J. 2019;33:11045-59. https://doi.org/10.1096/fj.201900078RR.

62. Yuan B, Sun R, Du Y, Jia Z, Yao W, Yang J. STAT3-induced upregulation of IncRNA CASC9 promotes the progression of bladder cancer by interacting with $\mathrm{EZH} 2$ and affecting the expression of PTEN. Onco Targets Ther. 2020;13:9147-57.

63. Liu Z, Wang W, Jiang J, Bao $E, X u$ D, Zeng $Y$, et al. Downregulation of GAS5 promotes bladder cancer cell proliferation, partly by regulating CDK6. PLoS ONE. 2013;8:e73991. https://doi.org/10.1371/journal.pone.0073991.

64. Cao Q, Wang N, Qi J, Gu Z, Shen H. Long noncoding RNAGAS5 acts as a tumor suppressor in bladder transitional cell carcinoma via regulation of chemokine (CC motif) ligand 1 expression. Mol Med Rep. 2016;13:27-34. https://doi.org/ 10.3892/mmr.2015.4503.

65. Zhang L, Liu B, Deng QH, Li JX. LncRNA BRE-AS1 acts as a tumor suppressor factor in bladder cancer via mediating STAT3. Eur Rev Med Pharm Sci. 2020;24:5320-8. https://doi.org/10.26355/eurrev_202005_21314.

66. He H, Wu S, Ai K, Xu R, Zhong Z, Wang Y, et al.LncRNA ZNF503-AS1 acts as a tumor suppressor in bladder cancer by up-regulating $\mathrm{Ca}(2+)$ concentration via transcription factor GATA6.Cell Oncol.2020 https://doi.org/10.1007/s13402-02000563-z.

67. Ye T, Ding W, Wang N, Huang H, Pan Y, Wei A. Long noncoding RNA linc00346 promotes the malignant phenotypes of bladder cancer. Biochem Biophys Res Commun. 2017;491:79-84. https://doi.org/10.1016/j.bbrc.2017.07.045.

68. Cheng J, Chen J, Zhang X, Mei H, Wang F, Cai Z. Overexpression of CRNDE promotes the progression of bladder cancer. Biomed Pharmacother. 2018;99:638-44. https://doi.org/10.1016/j.biopha.2017.12.055. 
69. Zhang C, Wang W, Lin J, Xiao J, Tian Y. IncRNA CCAT1 promotes bladder cancer cell proliferation, migration and invasion. Int Braz J Urol. 2019;45:549-59. https:// doi.org/10.1590/S1677-5538.IBJU.2018.0450

70. Gui JQ, Zhang C, Yang HB, Yu YW, Cui MR, Wang WS. LncRNA AFAP1-AS1 promotes proliferation ability and invasiveness of bladder cancer cells. Eur Rev Med Pharm Sci. 2020;24:8747-55. https://doi.org/10.26355/eurrev_202009_22813.

71. Fang C, He W, Xu T, Dai J, Xu L, Sun F. Upregulation of IncRNA DGCR5 correlates with better prognosis and inhibits bladder cancer progression via transcriptionally facilitating P21 expression. J Cell Physiol. 2019;234:6254-62. https:// doi.org/10.1002/jcp.27356.

72. Koren E, Fuchs Y. Modes of regulated cell death in cancer. Cancer Discov. 2021;11:245-65. https://doi.org/10.1158/2159-8290.CD-20-0789.

73. Mizushima N, Levine B, Cuervo AM, Klionsky DJ. Autophagy fights disease through cellular self-digestion. Nature. 2008;451:1069-75. https://doi.org/ 10.1038/nature06639.

74. Ghafouri-Fard S, Shoorei H, Mohaqiq M, Majidpoor J, Mossavi MA. Taheri M, Exploring the role of non-coding RNAs in autophagy.Autophagy. 2021;1-22. https://doi.org/10.1080/15548627.2021.1883881.

75. Huang $H$, Fan X, Zhang $X$, Xie Y, Ji Z. LncRNA CARLo-7 facilitates proliferation, migration, invasion, and EMT of bladder cancer cells by regulating Wnt/betacatenin and JAK2/STAT3 signaling pathways. Transl Androl Urol. 2020;9:2251-61. https://doi.org/10.21037/tau-20-1293.

76. Ying $L$, Huang $Y$, Chen $H$, Wang $Y$, Xia L, Chen $Y$, et al. Downregulated MEG3 activates autophagy and increases cell proliferation in bladder cancer. Mol Biosyst. 2013;9:407-11. https://doi.org/10.1039/c2mb25386k.

77. Liu G, Zhao X, Zhou J, Cheng $X$, Ye Z, Ji Z. Long non-coding RNA MEG3 suppresses the development of bladder urothelial carcinoma by regulating miR-96 and TPM1. Cancer Biol Ther. 2018;19:1039-56. https://doi.org/ 10.1080/15384047.2018.1480279.

78. Wu J, Li W, Ning J, Yu W, Rao T, Cheng F. Long noncoding RNA UCA1 targets miR-582-5p and contributes to the progression and drug resistance of bladder cancer cells through ATG7-mediated autophagy inhibition. Onco Targets Ther. 2019;12:495-508. https://doi.org/10.2147/OTT.S183940.

79. Kahn M. Can we safely target the WNT pathway? Nat Rev Drug Discov. 2014;13:513-32. https://doi.org/10.1038/nrd4233.

80. Pecina-Slaus N. Wht signal transduction pathway and apoptosis: a review. Cancer Cell Int. 2010;10:22 https://doi.org/10.1186/1475-2867-10-22.

81. Liu Q, Liu H, Cheng H, Li Y, Li X, Zhu C. Downregulation of long noncoding RNA TUG1 inhibits proliferation and induces apoptosis through the TUG1/miR-142/ ZEB2 axis in bladder cancer cells. Onco Targets Ther. 2017;10:2461-71.https:// doi.org/10.2147/OTT.S124595.

82. Li J, Li Y, Meng F, Fu L. Kong C, Knockdown of long non-coding RNA linc00511 suppresses proliferation and promotes apoptosis of bladder cancer cells via suppressing Wnt/beta-catenin signaling pathway. Biosci Rep. 2018;38. https://doi.org/10.1042/BSR20171701.

83. Cao $\mathrm{X}, \mathrm{Xu}$ J, Yue D. LncRNA-SNHG16 predicts poor prognosis and promotes tumor proliferation through epigenetically silencing p21 in bladder cancer. Cancer Gene Ther. 2018;25:10-17.https://doi.org/10.1038/s41417-017-0006-x

84. Feng F, Chen A, Huang J, Xia Q, Chen Y, Jin X. Long noncoding RNA SNHG16 contributes to the development of bladder cancer via regulating miR-98/STAT3/ Wnt/beta-catenin pathway axis. J Cell Biochem. 2018;119:9408-18. https://doi. org/10.1002/jcb.27257.

85. Han $Y$, Liu $Y$, Zhang $H$, Wang $T$, Diao R, Jiang Z, et al. Hsa-miR-125b suppresses bladder cancer development by down-regulating oncogene SIRT7 and oncogenic long noncoding RNA MALAT1. FEBS Lett. 2013. https://doi.org/10.1016/j. febslet.2013.10.023.

86. Xie $\mathrm{H}$, Liao $\mathrm{X}$, Chen $\mathrm{Z}$, Fang $\mathrm{Y}$, He $A$, Zhong $\mathrm{Y}$, et al. LncRNA MALAT1 inhibits apoptosis and promotes invasion by antagonizing miR-125b in bladder cancer cells. J Cancer. 2017;8:3803-11. https://doi.org/10.7150/jca.21228.

87. Shan G, Tang T, Xia Y, Qian HJ. Long non-coding RNA NEAT1 promotes bladder progression through regulating miR-410 mediated HMGB1. Biomed Pharmacother. 2020;121:109248 https://doi.org/10.1016/j.biopha.2019.109248.

88. Feng R, Li Z, Wang X, Ge G, Jia Y, Wu D, et al. Silenced IncRNA SNHG14 restrains the biological behaviors of bladder cancer cells via regulating microRNA-2113p/ESM1 axis. Cancer Cell Int. 2021;21:67. https://doi.org/10.1186/s12935-02001717-7.

89. Wang $X$, Zhang R, Wu S, Shen L, Ke M, Ouyang Y, et al. Super-enhancer LncRNA LINC00162 promotes progression of bladder cancer. iScience. 2020;23:101857 https://doi.org/10.1016/j.isci.2020.101857.

90. Xu C, Zhou J, Wang Y, Wang A, Su L, Liu S, et al. Inhibition of malignant human bladder cancer phenotypes through the down-regulation of the long noncoding RNA SNHG7. J Cancer. 2019;10:539-46.https://doi.org/10.7150/jca.25507.

91. Zhong $X$, Long $Z$, Wu S, Xiao $M$, Hu W. LncRNA-SNHG7 regulates proliferation, apoptosis and invasion of bladder cancer cells assurance guidelines. J BUON. 2018;23:776-81.
92. Zhu H, Li X, Song Y, Zhang P, Xiao Y, Xing Y. Long non-coding RNA ANRIL is upregulated in bladder cancer and regulates bladder cancer cell proliferation and apoptosis through the intrinsic pathway. Biochem Biophys Res Commun. 2015;467:223-8. https://doi.org/10.1016/j.bbrc.2015.10.002

93. Wu X, Yan T, Wang Z, Wu X, Cao G, Zhang C. LncRNA ZEB2-AS1 promotes bladder cancer cell proliferation and inhibits apoptosis by regulating miR-27b. Biomed Pharmacother. 2017;96:299-304. https://doi.org/10.1016/j.biopha.2017.08.060.

94. Wang Y, Shi F, Xia Y, Zhao H. LncRNA OIP5-AS1 predicts poor prognosis and regulates cell proliferation and apoptosis in bladder cancer. J Cell Biochem. 2018. https://doi.org/10.1002/jcb.28024.

95. Hu X, Feng H, Huang H, Gu W, Fang Q, Xie $Y$, et al. Downregulated long noncoding RNA PART1 inhibits proliferation and promotes apoptosis in bladder cancer. Technol Cancer Res Treat. 2019;18:1533033819846638. https://doi.org/ $10.1177 / 1533033819846638$.

96. Polacheck WJ, Zervantonakis IK, Kamm RD. Tumor cell migration in complex microenvironments. Cell Mol Life Sci. 2013;70:1335-56. https://doi.org/10.1007/ s00018-012-1115-1.

97. Luo M, Li Z, Wang W, Zeng Y, Liu Z, Qiu J. Long non-coding RNA H19 increases bladder cancer metastasis by associating with EZH2 and inhibiting E-cadherin expression. Cancer Lett. 2013;333:213-21. https://doi.org/10.1016/j. canlet.2013.01.033.

98. Lv $M$, Zhong Z, Huang $M$, Tian $Q$, Jiang $R$, Chen J. IncRNA H19 regulates epithelial-mesenchymal transition and metastasis of bladder cancer by miR29b-3p as competing endogenous RNA. Biochim Biophys Acta Mol Cell Res. 2017;1864:1887-99. https://doi.org/10.1016/j.bbamcr.2017.08.001.

99. Guo J, Chen Z, Jiang H, Yu Z, Peng J, Xie J, et al. The IncRNA DLX6-AS1 promoted cell proliferation, invasion, migration and epithelial-to-mesenchymal transition in bladder cancer via modulating Wnt/beta-catenin signaling pathway. Cancer Cell Int. 2019;19:312. https://doi.org/10.1186/s12935-019-1010-z.

100. Fang C, Xu L, He W, Dai J, Sun F. Long noncoding RNA DLX6-AS1 promotes cell growth and invasiveness in bladder cancer via modulating the miR-223HSP90B1 axis. Cell Cycle. 2019;18:3288-99. https://doi.org/10.1080/ 15384101.2019.1673633.

101. Wang $H$, Niu $X$, Jiang $H$, Mao $F$, Zhong B, Jiang $X$, et al. Long non-coding RNA DLX6-AS1 facilitates bladder cancer progression through modulating miR-1955p/VEGFA signaling pathway. Aging. 2020;12:16021-34. https://doi.org/ 10.18632/aging.103374.

102. Zhan Y, Zhang L, Yu S, Wen J, Liu Y, Zhang X. Long non-coding RNA CASC9 promotes tumor growth and metastasis via modulating FZD6/Wnt/beta-catenin signaling pathway in bladder cancer. J Exp Clin Cancer Res. 2020;39:136. https:// doi.org/10.1186/s13046-020-01624-9.

103. Chen $Y$, Peng $Y, X u Z, G e$, Xiang $X$, Zhang $T$, et al. Knockdown of IncRNA SNHG7 inhibited cell proliferation and migration in bladder cancer through activating Wnt/beta-catenin pathway. Pathol Res Pr. 2019;215:302-7. https://doi. org/10.1016/j.prp.2018.11.015.

104. Wang W, Chen S, Song X, Gui J, Li Y, Li M. ELK1/IncRNA-SNHG7/miR-2682-5p feedback loop enhances bladder cancer cell growth. Life Sci. 2020;262:118386. https://doi.org/10.1016/j.lfs.2020.118386.

105. Jiang F, Qi W, Wang Y, Wang W, Fan L. IncRNA PEG10 promotes cell survival, invasion and migration by sponging miR-134 in human bladder cancer. Biomed Pharmacother. 2019;114:108814. https://doi.org/10.1016/j.biopha.2019.108814.

106. Liang T, Wang Y, Wang Y, Wang Y. Long noncoding RNA PEG10 facilitates bladder cancer cells proliferation, migration, and invasion via repressing microRNA-29b. J Cell Physiol. 2019;234:19740-9. https://doi.org/10.1002/ jcp.28574.

107. Yu C, Longfei L, Long W, Feng Z, Chen J, Chao L, et al. LncRNA PVT1 regulates VEGFC through inhibiting miR-128 in bladder cancer cells. J Cell Physiol. 2019;234:1346-53. https://doi.org/10.1002/jcp.26929.

108. Chen M, Zhang R, Lu L, Du J, Chen C, Ding K, et al. LncRNA PVT1 accelerates malignant phenotypes of bladder cancer cells by modulating miR-194-5p/ BCLAF1 axis as a ceRNA. Aging. 2020;12:22291-312. https://doi.org/10.18632/ aging.202203.

109. Liu Y, Wu G. NNT-AS1 enhances bladder cancer cell growth by targeting miR1301-3p/PODXL axis and activating Wnt pathway. Neurourol Urodyn. 2020;39:547-57. https://doi.org/10.1002/nau.24238.

110. Zhao Q, Gao S, Du Q, Liu Y. Long non-coding RNA SNHG20 promotes bladder cancer via activating the Wnt/beta-catenin signalling pathway. Int J Mol Med. 2018;42:2839-48. https://doi.org/10.3892/ijmm.2018.3819.

111. Xie $H$, Huang $H$, Huang $W$, Xie Z, Yang $Y$, Wang F. LncRNA miR143HG suppresses bladder cancer development through inactivating $\mathrm{Wnt} /$ beta-catenin pathway by modulating miR-1275/AXIN2 axis. J Cell Physiol. 2019;234:11156-64. https:// doi.org/10.1002/jcp.27764.

112. Liu X, Ke J, Gu L, Tang H, Luo X. Long non-coding RNA LINC00675 is associated with bladder cancer metastasis and patient survival. J Gene Med. 2020;22:e3210 https://doi.org/10.1002/jgm.3210. 
113. Gao R, Zhang N, Yang J, Zhu Y, Zhang Z, Wang J, et al. Long non-coding RNA ZEB1-AS1 regulates miR-200b/FSCN1 signaling and enhances migration and invasion induced by TGF-beta1 in bladder cancer cells. J Exp Clin Cancer Res. 2019;38:111. https://doi.org/10.1186/s13046-019-1102-6

114. Zhao X, Wang D, Ding Y, Zhou J, Liu G, Ji Z. IncRNA ZEB1-AS1 promotes migration and metastasis of bladder cancer cells by post-transcriptional activation of ZEB1. Int J Mol Med. 2019;44:196-206. https://doi.org/10.3892/ ijmm.2019.4187.

115. Xu G, Yang H, Liu M, Niu J, Chen W, Tan X, et al. IncRNA TINCR facilities bladder cancer progression via regulating miR7 and mTOR. Mol. Med Rep. 2020;22:4243-53. https://doi.org/10.3892/mmr.2020.11530.

116. Sun $X$, Du P, Yuan W, Du Z, Yu M, Yu X, et al. Long non-coding RNA HOTAIR regulates cyclin $\mathrm{J}$ via inhibition of microRNA-205 expression in bladder cancer. Cell Death Dis. 2015;6:e1907. https://doi.org/10.1038/cddis.2015.269.

117. Tang C, Wu Y, Wang X, Chen K, Tang Z, Guo X. LncRNA MAFG-AS1 regulates miR-125b-5p/SphK1 axis to promote the proliferation, migration, and invasion of bladder cancer cells. Hum Cell. 2021. https://doi.org/10.1007/s13577-02000470-3.

118. Li D, Zhong S, Zhu Z, Jiang X, Zhang J, Gu J, et al. LncRNA MAFG-AS1 promotes the progression of bladder cancer by targeting the miR-143-3p/COX-2 axis. Pathobiology. 2020;87:345-55. https://doi.org/10.1159/000509957.

119. Liu D, Li Y, Luo G, Xiao X, Tao D, Wu X, et al. LncRNA SPRY4-IT1 sponges miR101-3p to promote proliferation and metastasis of bladder cancer cells through up-regulating EZH2. Cancer Lett. 2017;388:281-91. https://doi.org/10.1016/j. canlet.2016.12.005.

120. Chen JB, Zhu YW, Guo X, Yu C, Liu PH, Li C, et al. Microarray expression profiles analysis revealed IncRNA OXCT1-AS1 promoted bladder cancer cell aggressiveness via miR-455-5p/JAK1 signaling. J Cell Physiol. 2019;234:13592-601. https://doi.org/10.1002/jcp.28037.

121. Yuan $S$, Luan $X$, Chen $H$, Shi $X$, Zhang $X$. Long non-coding RNA EGFR-AS1 sponges micorRNA-381 to upregulate ROCK2 in bladder cancer. Oncol Lett. 2020;19:1899-905. https://doi.org/10.3892/ol.2020.11283.

122. Zhao C, Li Y, Hu X, Wang R, He W, Wang L, et al. LncRNA HCP5 promotes cell invasion and migration by sponging miR-29b-3p in human bladder cancer. Onco Targets Ther. 2020;13:11827-38. https://doi.org/10.2147/OTT.S249770.

123. Wu S, Xu R, Zhu X, He H, Zhang J, Zeng Q, et al. The long noncoding RNA LINC01140/miR-140-5p/FGF9 axis modulates bladder cancer cell aggressiveness and macrophage M2 polarization. Aging. 2020;12:25845-64. https://doi.org/ 10.18632/aging.202147.

124. Wang F, Zu Y, Zhu S, Yang Y, Huang W, Xie H, et al. Long noncoding RNA MAGI2AS3 regulates CCDC19 expression by sponging miR-15b-5p and suppresses bladder cancer progression. Biochem Biophys Res Commun. 2018;507:231-5. https://doi.org/10.1016/j.bbrc.2018.11.013.

125. Tang C, Cai Y, Jiang H, Lv Z, Yang C, Xu H, et al. LncRNA MAGI2-AS3 inhibits bladder cancer progression by targeting the miR-31-5p/TNS1 axis. Aging. 2020;12:25547-63. https://doi.org/10.18632/aging.104162.

126. Zhang Z, Ao P, Han H, Zhang Q, Chen Y, Han J, et al. LncRNA PLAC2 upregulates miR-663 to downregulate TGF-beta1 and suppress bladder cancer cell migration and invasion. BMC Urol. 2020;20:94 https://doi.org/10.1186/ s12894-020-00663-w.

127. Li G, Zhang Y, Mao J, Hu P, Chen Q, Ding W, et al. IncRNA TUC338 is a potential diagnostic biomarker for bladder cancer. J Cell Biochem. 2019;120:18014-9. https://doi.org/10.1002/jcb.29104.

128. Guo Y, Chen D, Su X, Chen J, Li Y. The IncRNA ELF3-AS1 promotes bladder cancer progression by interaction with Kruppel-like factor 8 . Biochem Biophys Res Commun. 2019;508:762-8. https://doi.org/10.1016/j.bbrc.2018.11.183.

129. Yuan S, Luan X, Han G, Guo K, Wang S, Zhang X. LINC01638 IncRNA mediates the postoperative distant recurrence of bladder cancer by upregulating ROCK2. Oncol Lett. 2019;18:5392-8. https://doi.org/10.3892/ol.2019.10924.

130. Xia W, Chen C, Zhang MR, Zhu LN. LncRNA PCAT6 aggravates the progression of bladder cancer cells by targeting miR-513a-5p. Eur Rev Med Pharm Sci. 2020;24:9908-14. https://doi.org/10.26355/eurrev_202010_23201.

131. Wang $Y$, Sun $Q$, Ji L, Wang G, Niu X, Sun S. IncRNA MORT Regulates Bladder Cancer Behaviors by Downregulating MicroRNA-146a-5p. Nephron. 2020;144:351-7. https://doi.org/10.1159/000506291.

132. Cao HL, Liu ZJ, Huang PL, Yue YL, Xi J. N. IncRNA-RMRP promotes proliferation, migration and invasion of bladder cancer via miR-206. Eur Rev Med Pharm Sci. 2019;23:1012-21. https://doi.org/10.26355/eurrev_201902_16988.

133. Feng Z, Wang B. Long non-coding RNA HNF1A-AS1 promotes cell viability and migration in human bladder cancer. Oncol Lett. 2018;15:4535-40. https://doi. org/10.3892/ol.2018.7878.

134. Zhan Y, Lin J, Liu Y, Chen M, Chen X, Zhuang C, et al. Up-regulation of long noncoding RNA PANDAR is associated with poor prognosis and promotes tumorigenesis in bladder cancer. J Exp Clin Cancer Res. 2016;35:83. https://doi.org/ 10.1186/s13046-016-0354-7.
135. Wen L, Zhang X, Bian J, Han L, Huang H, He M, et al. The long non-coding RNA LINC00460 predicts the prognosis and promotes the proliferation and migration of cells in bladder urothelial carcinoma. Oncol Lett. 2019;17:3874-80. https://doi. org/10.3892/ol.2019.10023.

136. Luo J, Chen J, Li H, Yang Y, Yun H, Yang S, et al. LncRNA UCA1 promotes the invasion and EMT of bladder cancer cells by regulating the miR-143/HMGB1 pathway. Oncol Lett. 2017;14:5556-62. https://doi.org/10.3892/ol.2017.6886.

137. Dai G, Huang C, Yang J, Jin L, Fu K, Yuan F, et al. LncRNA SNHG3 promotes bladder cancer proliferation and metastasis through miR-515-5p/GINS2 axis. J Cell Mol Med. 2020;24:9231-43. https://doi.org/10.1111/jcmm.15564.

138. Gao Z, Li S, Zhou X, Li H, He S. Knockdown of IncRNA ZNRD1-AS1 inhibits progression of bladder cancer by regulating miR-194 and ZEB1. Cancer Med. 2020;9:7695-705. https://doi.org/10.1002/cam4.3373.

139. Chen W, Jiang $T$, Mao $H$, Gao R, Zhang H, He Y, et al. SNHG16 regulates invasion and migration of bladder cancer through induction of epithelial-tomesenchymal transition. Hum Cell. 2020;33:737-49. https://doi.org/10.1007/ s13577-020-00343-9.

140. Wang C, Tao W, Ni S, Chen Q. Upregulation of IncRNA snoRNA host gene 6 regulates NUAK family SnF1-like kinase- 1 expression by competitively binding microRNA-125b and interacting with Snail1/2 in bladder cancer. J Cell Biochem. 2019;120:357-67. https://doi.org/10.1002/jcb.27387.

141. Fan $Y$, Shen $B$, Tan $M, M u ~ X, Q$ in $Y$, Zhang F, et al. TGF-beta-induced upregulation of malat 1 promotes bladder cancer metastasis by associating with suz12. Clin Cancer Res. 2014;20:1531-41. https://doi.org/10.1158/1078-0432. CCR-13-1455

142. Jiao D, Li Z, Zhu M, Wang Y, Wu G, Han X. LncRNA MALAT1 promotes tumor growth and metastasis by targeting miR-124/foxq 1 in bladder transitional cell carcinoma (BTCC). Am J Cancer Res. 2018;8:748-60.

143. Wang J, Xing H, Nikzad AA, Liu B, Zhang $Y$, Li S, et al. Long noncoding RNA MNX1 antisense RNA 1 exerts oncogenic functions in bladder cancer by regulating miR-218-5p/RAB1A axis. J Pharm Exp. Ther. 2020;372:237-47. https://doi. org/10.1124/jpet.119.262949.

144. Miao L, Liu HY, Zhou C, He X. LINC00612 enhances the proliferation and invasion ability of bladder cancer cells as ceRNA by sponging miR-590 to elevate expression of PHF14. J Exp Clin Cancer Res. 2019;38:143. https://doi.org/ 10.1186/s13046-019-1149-4.

145. Li W, Li Y, Ma W, Zhou J, Sun Z, Yan X. Long noncoding RNA AC114812.8 promotes the progression of bladder cancer through miR-371b-5p/FUT4 axis. Biomed Pharmacother. 2020;121:109605. https://doi.org/10.1016/j. biopha.2019.109605.

146. Liao C, Long Z, Zhang X, Cheng J, Qi F, Wu S, et al. LncARSR sponges miR-129-5p to promote proliferation and metastasis of bladder cancer cells through increasing SOX4 expression. Int J Biol Sci. 2020;16:1-11. https://doi.org/10.7150/ ijbs.39461.

147. Meng L, Xing Z, Guo Z, Liu Z. LINC01106 post-transcriptionally regulates ELK3 and HOXD8 to promote bladder cancer progression. Cell Death Dis. 2020;11:1063. https://doi.org/10.1038/s41419-020-03236-9.

148. Zhang $Z$, Chen $F$, Zhan $H$, Chen $L$, Deng $Q$, Xiong $T$, et al. IncRNA CASC9 sponges miR7583p to promote proliferation and EMT in bladder cancer by upregulating TGFbeta2. Oncol Rep. 2021;45:265-77. https://doi.org/10.3892/or.2020.7852.

149. Zhu X, Li Y, Zhao S, Zhao S. LSINCT5 activates Wnt/beta-catenin signaling by interacting with NCYM to promote bladder cancer progression. Biochem Biophys Res Commun. 2018;502:299-306. https://doi.org/10.1016/j. bbrc.2018.05.076.

150. Shen $\mathrm{D}, \mathrm{Xu} J, \mathrm{Cao} X, \mathrm{Cao} X$, Tan $\mathrm{H}$, Deng $\mathrm{H}$. Long noncoding RNA MAGI2-AS3 inhibits bladder cancer progression through MAGI2/PTEN/epithelial-mesenchymal transition (EMT) axis. Cancer Biomark. 2020. https://doi.org/10.3233/CBM201421.

151. Qiu F, Zhang MR, Zhou Z, Pu JX, Zhao X. J. IncRNA MIR503HG functioned as a tumor suppressor and inhibited cell proliferation, metastasis and epithelialmesenchymal transition in bladder cancer. J Cell Biochem. 2019;120:10821-9. https://doi.org/10.1002/jcb.28373.

152. Tuo Z, Zhang J, Xue W. LncRNA TP73-AS1 predicts the prognosis of bladder cancer patients and functions as a suppressor for bladder cancer by EMT pathway. Biochem Biophys Res Commun. 2018;499:875-81. https://doi.org/ 10.1016/j.bbrc.2018.04.010.

153. Xiao M, Liu J, Xiang L, Zhao K, He D, Zeng Q, et al. MAFG-AS1 promotes tumor progression via regulation of the HuR/PTBP1 axis in bladder urothelial carcinoma. Clin Transl Med. 2020;10:e241. https://doi.org/10.1002/ctm2.241.

154. Qin Z, Wang Y, Tang J, Zhang L, Li R. Xue J, et al. High LINC01605 expression predicts poor prognosis and promotes tumor progression via up-regulation of MMP9 in bladder cancer. Biosci Rep. 2018;38. https://doi.org/10.1042/ BSR20180562.

155. Wang X, Wang L, Gong Y, Liu Z, Qin Y, Chen J, et al. Long noncoding RNA LINC01296 promotes cancer-cell proliferation and metastasis in urothelial 
carcinoma of the bladder. Onco Targets Ther. 2019;12:75-85. https://doi.org/ 10.2147/OTT.S192809.

156. Xiong T, Huang C, Li J, Yu S, Chen F, Zhang Z, et al. LncRNA NRON promotes the proliferation, metastasis and EMT process in bladder cancer. J Cancer. 2020;11:1751-60. https://doi.org/10.7150/jca.37958.

157. Hisano Y, Hla T. Bioactive lysolipids in cancer and angiogenesis. Pharm Ther. 2019;193:91-98. https://doi.org/10.1016/j.pharmthera.2018.07.006.

158. Liu B, Gao W, Sun W, Li L, Wang C, Yang X, et al. Promoting roles of long noncoding RNA FAM83H-AS1 in bladder cancer growth, metastasis, and angiogenesis through the c-Myc-mediated ULK3 upregulation. Cell Cycle. 2020;19:3546-62. https://doi.org/10.1080/15384101.2020.1850971.

159. Chi $H$, Yang $R$, Zheng $X$, Zhang $L$, Jiang R. Chen J, LncRNA RP11-79H23.3 functions as a competing endogenous RNA to regulate PTEN expression through sponging hsa-miR-107 in the development of bladder cancer. Int J Mol Sci. 2018;19. https://doi.org/10.3390/ijms19092531.

160. Kurtova AV, Xiao J, Mo Q, Pazhanisamy S, Krasnow R, Lerner SP, et al. Blocking PGE2-induced tumour repopulation abrogates bladder cancer chemoresistance. Nature. 2015;517:209-13. https://doi.org/10.1038/nature14034.

161. Herr HW, Dotan Z, Donat SM, Bajorin DF. Defining optimal therapy for muscle invasive bladder cancer. J Urol. 2007;177:437-43. https://doi.org/10.1016/j. juro.2006.09.027.

162. Yu G, Zhou H, Yao W, Meng L, Lang B. IncRNA TUG1 promotes cisplatin resistance by regulating CCND2 via epigenetically silencing miR-194-5p in bladder cancer. Mol Ther Nucleic Acids. 2019;16:257-71. https://doi.org/10.1016/j. omtn.2019.02.017.

163. Sun Z, Huang G, Cheng H. Transcription factor Nrf2 induces the up-regulation of InCRNA TUG1 to promote progression and adriamycin resistance in urothelial carcinoma of the bladder. Cancer Manag Res. 2019;11:6079-90. https://doi.org/ 10.2147/CMAR.S200998.

164. Dudek AM, van Kampen JGM, Witjes JA, Kiemeney L, Verhaegh GW. LINC00857 expression predicts and mediates the response to platinum-based chemotherapy in muscle-invasive bladder cancer. Cancer Med. 2018. https://doi. org/10.1002/cam4.1570.

165. Chen X, Liu M, Meng F, Sun B, Jin X, Jia C. The long noncoding RNA HIF1A-AS2 facilitates cisplatin resistance in bladder cancer. J Cell Biochem. 2019;120:243-52. https://doi.org/10.1002/jcb.27327.

166. Li Y, Shi B, Dong F, Zhu X, Liu B, Liu Y. Long non-coding RNA DLEU1 promotes cell proliferation, invasion, and confers cisplatin resistance in bladder cancer by regulating the miR-99b/HS3ST3B1 axis. Front Genet. 2019;10:280. https://doi. org/10.3389/fgene.2019.00280.

167. Liu P, Li X, Cui Y, Chen J, Li C, Li Q, et al. LnCRNA-MALAT1 mediates cisplatin resistance via miR-101-3p/VEGF-C pathway in bladder cancer. Acta Biochim Biophys Sin. 2019;51:1148-57. https://doi.org/10.1093/abbs/gmz112.

168. Chen J, Li Y, Li Z, Cao L. LncRNA MST1P2/miR-133b axis affects the chemoresistance of bladder cancer to cisplatin-based therapy via Sirt1/p53 signaling. J Biochem Mol. Toxicol. 2020;34:e22452. https://doi.org/10.1002/jbt.22452.

169. Fan $Y$, Shen B, Tan M, Mu X, Qin Y, Zhang F, et al. Long non-coding RNA UCA1 increases chemoresistance of bladder cancer cells by regulating Wnt signaling. FEBS J. 2014;281:1750-8. https://doi.org/10.1111/febs.12737

170. Feng SQ, Zhang XY, Fan HT, Sun QJ, Zhang M. Up-regulation of LncRNA MEG3 inhibits cell migration and invasion and enhances cisplatin chemosensitivity in bladder cancer cells. Neoplasma. 2018;65:925-32. https://doi.org/10.4149/ neo_2018_180125N55.

171. Kim JJ, Tannock IF. Repopulation of cancer cells during therapy: an important cause of treatment failure. Nat Rev Cancer. 2005;5:516-25. https://doi.org/ 10.1038/nrc1650.

172. Zhuang J, Shen L, Yang L, Huang X, Lu Q, Cui Y, et al. TGFbeta1 promotes gemcitabine resistance through regulating the LnCRNA-LET/NF90/miR-145 signaling axis in bladder cancer. Theranostics. 2017;7:3053-67. https://doi.org/ 10.7150/thno.19542.

173. An Q, Zhou L, Xu N. Long noncoding RNA FOXD2-AS1 accelerates the gemcitabine-resistance of bladder cancer by sponging miR-143. Biomed Pharmacother. 2018;103:415-20. https://doi.org/10.1016/j.biopha.2018.03.138.

174. Xie $\mathrm{D}$, Zhang $\mathrm{H}$, Shang $\mathrm{C}$. Long non-coding RNA CDKN2B antisense RNA 1 gene inhibits Gemcitabine sensitivity in bladder urothelial carcinoma. J Cancer. 2018;9:2160-6. https://doi.org/10.7150/jca.25236.

175. Li B, Xie D, Zhang H. Long non-coding RNA GHET1 contributes to chemotherapeutic resistance to Gemcitabine in bladder cancer. Cancer Chemother Pharm. 2019;84:187-94. https://doi.org/10.1007/s00280-019-03873-8.

176. Pan J, Li X, Wu W, Xue M, Hou H, Zhai W, et al. Long non-coding RNA UCA1 promotes cisplatin/gemcitabine resistance through CREB modulating miR-196a$5 p$ in bladder cancer cells. Cancer Lett. 2016;382:64-76. https://doi.org/10.1016/ j.canlet.2016.08.015.

177. Shang $C$, Guo $Y$, Zhang $H$, Xue YX. Long noncoding RNA HOTAIR is a prognostic biomarker and inhibits chemosensitivity to doxorubicin in bladder transitional cell carcinoma. Cancer Chemother Pharm. 2016;77:507-13. https://doi.org/ 10.1007/s00280-016-2964-3.

178. Zhang $\mathrm{H}$, Guo $\mathrm{Y}$, Song $\mathrm{Y}$, Shang $\mathrm{C}$. Long noncoding RNA GAS5 inhibits malignant proliferation and chemotherapy resistance to doxorubicin in bladder transitional cell carcinoma. Cancer Chemother Pharm. 2017;79:49-55. https://doi.org/ 10.1007/s00280-016-3194-4.

179. Tan J, Qiu K, Li M, Liang Y. Double-negative feedback loop between long noncoding RNA TUG1 and miR-145 promotes epithelial to mesenchymal transition and radioresistance in human bladder cancer cells. FEBS Lett. 2015;589:3175-81. https://doi.org/10.1016/j.febslet.2015.08.020.

180. Jiang $\mathrm{H}, \mathrm{Hu} X$, Zhang $\mathrm{H}$, Li W. Down-regulation of LncRNA TUG1 enhances radiosensitivity in bladder cancer via suppressing HMGB1 expression. Radiat Oncol. 2017;12:65. https://doi.org/10.1186/s13014-017-0802-3.

181. Nguyen LV, Vanner R, Dirks P, Eaves CJ. Cancer stem cells: an evolving concept. Nat Rev Cancer. 2012;12:133-43. https://doi.org/10.1038/nrc3184.

182. Yang L, Xue Y, Liu J, Zhuang J, Shen L, Shen B, et al. Long noncoding RNA ASAP1-IT1 promotes cancer stemness and predicts a poor prognosis in patients with bladder cancer. Neoplasma. 2017;64:847-55. https://doi.org/10.4149/ neo_2017_606.

183. Qiao Z, Dai H, Zhang Y, Li Q, Zhao M, Yue T. LncRNA NCK1-AS1 promotes cancer cell proliferation and increase cell stemness in urinary bladder cancer patients by downregulating miR-143. Cancer Manag Res. 2020;12:1661-8. https://doi. org/10.2147/CMAR.S223172.

184. Wang F, Wu D, Chen J, Chen S, He F, Fu H, et al. Long non-coding RNA HOXAAS2 promotes the migration, invasion and stemness of bladder cancer via regulating miR-125b/Smad2 axis. Exp Cell Res. 2019;375:1-10. https://doi.org/ 10.1016/j.yexcr.2018.11.005.

185. Zhan Y, Chen Z, He S, Gong Y, He A, Li Y, et al. Long non-coding RNA SOX2OT promotes the stemness phenotype of bladder cancer cells by modulating SOX2. Mol Cancer. 2020;19:25. https://doi.org/10.1186/s12943-020-1143-7.

186. Chen X, Xie R, Gu P, Huang M, Han J, Dong W, et al. Long noncoding RNA LBCS inhibits self-renewal and chemoresistance of bladder cancer stem cells through epigenetic silencing of SOX2. Clin Cancer Res. 2019;25:1389-403. https://doi. org/10.1158/1078-0432.CCR-18-1656.

187. Rosiello G, Palumbo C, Deuker M, Stolzenbach LF, Martin T, Tian Z, et al. Sex- and age-related differences in the distribution of bladder cancer metastases. Jpn J Clin Oncol. 2021. https://doi.org/10.1093/jjco/hyaa273.

188. Xiang W, Lyu L, Huang T, Zheng F, Yuan J, Zhang C, et al. The long non-coding RNA SNHG1 promotes bladder cancer progression by interacting with miR-143$3 p$ and EZH2. J Cell Mol. Med. 2020;24:11858-73. https://doi.org/10.1111/ jcmm.15806.

189. Zhang D, Du D, Yi S, Li X. LncRNA PCAT6: A potential biomarker for diagnosis and prognosis of bladder cancer. Ann Diagn Pathol. 2020;49:151642. https://doi. org/10.1016/j.anndiagpath.2020.151642.

190. Li Z, Wang KE, Zhou XL, Zhou J, Ye CH. Long Non-Coding RNA Cancer Susceptibility Candidate 2a (CASC2a) Is a Marker of Early Recurrence After Radical Cystectomy in Patients with Urothelial Carcinoma of the Bladder. Med Sci Monit. 2018;24:438-47. https://doi.org/10.12659/msm.905393.

191. Liu A, Zhang Z, Xu W, Qin S, Hua M, Zeng S, et al. Overexpression of long noncoding RNA n346372 in bladder cancer tissues is associated with a poor prognosis. Mol Med Rep. 2018;18:5437-44. https://doi.org/10.3892/ mmr.2018.9597

192. Wang YH, Liu YH, Ji YJ, Wei Q, Gao TB. Upregulation of long non-coding RNA HNF1A-AS1 is associated with poor prognosis in urothelial carcinoma of the bladder. Eur Rev Med Pharm Sci. 2018;22:2261-5. https://doi.org/10.26355/ eurrev_201804_14813.

193. Han Y, Sun G. Overexpression of InCRNA TINCR is associated with high-grade, invasive, and recurring tumors, and facilitates proliferation in vitro and in vivo of urothelial carcinoma of the bladder. Urol Oncol. 2020;38:738 e731-738 e738. https://doi.org/10.1016/j.urolonc.2019.12.026.

194. Shan H, Yang Y, Zhu X, Han X, Zhang P, Zhang X. FAM83H-AS1 is associated with clinical progression and modulates cell proliferation, migration, and invasion in bladder cancer. J Cell Biochem. 2019;120:4687-93. https://doi.org/10.1002/ jcb.27758.

195. Avgeris M, Tsilimantou A, Levis PK, Tokas T, Sideris DC, Stravodimos K, et al. Loss of GAS5 tumour suppressor IncRNA: an independent molecular cancer biomarker for short-term relapse and progression in bladder cancer patients. $\mathrm{Br} J$ Cancer. 2018;119:1477-86. https://doi.org/10.1038/s41416-018-0320-6.

196. Qi D, Li J, Que B, Su J, Li M, Zhang C, et al. Long non-coding RNA DBCCR1-003 regulate the expression of DBCCR1 via DNMT1 in bladder cancer. Cancer Cell Int. 2016;16:81. https://doi.org/10.1186/s12935-016-0356-8.

197. Chen T, Xie W, Xie L, Sun Y, Zhang Y, Shen Z, et al. Expression of long noncoding RNA IncRNA-n336928 is correlated with tumor stage and grade and overall survival in bladder cancer. Biochem Biophys Res Commun. 2015;468:666-70. https://doi.org/10.1016/j.bbrc.2015.11.013. 


\section{ACKNOWLEDGEMENTS}

We thank the colleagues in our laboratory who contributed to the accomplishment of this study.

\section{AUTHOR CONTRIBUTIONS}

$\mathrm{YZ}, \mathrm{XC}$, and $\mathrm{XJ}$ performed a literature search. $\mathrm{YZ}$ and $\mathrm{JL}$ designed all tables and figures. $\mathrm{YZ}, \mathrm{XC}$, and $\mathrm{XJ}$ wrote and revised the manuscript. All authors read and approved the final manuscript.

\section{FUNDING}

The authors received no specific funding for this work.

\section{COMPETING INTERESTS}

The authors declare no competing interests.

\section{ADDITIONAL INFORMATION}

Correspondence and requests for materials should be addressed to Xiaodong Jin.
Reprints and permission information is available at http://www.nature.com/ reprints

Publisher's note Springer Nature remains neutral with regard to jurisdictional claims in published maps and institutional affiliations.

\begin{abstract}
(c) (i) Open Access This article is licensed under a Creative Commons Attribution 4.0 International License, which permits use, sharing, adaptation, distribution and reproduction in any medium or format, as long as you give appropriate credit to the original author(s) and the source, provide a link to the Creative Commons license, and indicate if changes were made. The images or other third party material in this article are included in the article's Creative Commons license, unless indicated otherwise in a credit line to the material. If material is not included in the article's Creative Commons license and your intended use is not permitted by statutory regulation or exceeds the permitted use, you will need to obtain permission directly from the copyright holder. To view a copy of this license, visit http://creativecommons. org/licenses/by/4.0/.
\end{abstract}

(c) The Author(s) 2021 